\title{
Comparison between simulated and observed chemical composition of fine aerosols in Paris (France) during springtime: contribution of regional versus continental emissions
}

\author{
J. Sciare ${ }^{1}$, O. d'Argouges ${ }^{1}$, Q. J. Zhang ${ }^{2}$, R. Sarda-Estève ${ }^{1}$, C. Gaimoz ${ }^{1}$, V. Gros ${ }^{1}$, M. Beekmann ${ }^{2}$, and O. Sanchez \\ ${ }^{1}$ LSCE, Laboratoire des Sciences du Climat et de l'Environnement, unité mixte CEA-CNRS-UVSQ, \\ UMR8212, Gif-sur-Yvette, France \\ ${ }^{2}$ LISA, Laboratoire Interuniversitaire des Sciences Atmosphériques, Université Paris Est and Paris 7 , \\ CNRS, Créteil, France \\ ${ }^{3}$ AIRPARIF, Agence de Surveillance de la qualité de l'air, Paris, France
}

Received: 14 May 2010 - Published in Atmos. Chem. Phys. Discuss.: 7 July 2010

Revised: 10 November 2010 - Accepted: 7 December 2010 - Published: 16 December 2010

\begin{abstract}
Hourly concentrations of inorganic salts (ions) and carbonaceous material in fine aerosols (aerodynamic diameter, A.D. $<2.5 \mu \mathrm{m}$ ) have been determined experimentally from fast measurements performed for a 3 -week period in spring 2007 in Paris (France). The sum of these two chemical components (ions and carbonaceous aerosols) has shown to account for most of the fine aerosol mass $\left(\mathrm{PM}_{2.5}\right)$. This time-resolved dataset allowed investigating the factors controlling the levels of $\mathrm{PM}_{2.5}$ in Paris and showed that polluted periods with $\mathrm{PM}_{2.5}>15 \mu \mathrm{g} \mathrm{m}^{-3}$ were characterized by air masses of continental (North-Western Europe) origin and chemical composition made by $75 \%$ of ions. By contrast, periods with clean marine air masses have shown the lowest $\mathrm{PM}_{2.5}$ concentrations (typically of about $10 \mu \mathrm{g} \mathrm{m}^{-3}$ ); carbonaceous aerosols contributing for most of this mass (typically $75 \%$ ).

In order to better discriminate between local and continental contributions to the observed chemical composition and concentrations of $\mathrm{PM}_{2.5}$ over Paris, a comparative study was performed between this time-resolved dataset and the outputs of a chemistry transport model (CHIMERE), showing a relatively good capability of the model to reproduce the time-limited intense maxima observed in the field for $\mathrm{PM}_{2.5}$ and ion species. Different model scenarios were then investigated switching off local and European (North-Western and Central) emissions. Results of these scenarios have clearly
\end{abstract}

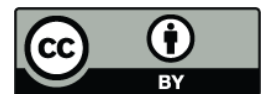

Correspondence to: J. Sciare (jean.sciare@1sce.ipsl.fr) shown that most of the ions observed over Paris during polluted periods, were either transported or formed in-situ from gas precursors transported from Northern Europe. On the opposite, long-range transport from Europe appeared to weakly contribute to the levels of carbonaceous aerosols observed over Paris.

The model failed to properly account for the concentration levels and variability of secondary organic aerosols (SOA) determined experimentally by the EC-tracer method. The abundance of SOA (relatively to organic aerosol, OA) was as much as $75 \%$, showing a weak dependence on air masses origin. Elevated SOA/OA ratios were also observed for air masses having residence time above ground of less than $10 \mathrm{~h}$, suggesting intense emissions and/or photochemical processes leading to rapid formation of secondary organic aerosols.

\section{Introduction}

Fine anthropogenic aerosols (with aerodynamic diameter, A.D., below $2.5 \mu \mathrm{m}$ ) have been recognized as having strong but poorly understood adverse effects on health (Nel, 2005); they may have also a significant climatic role at regional scales, inducing strong radiative forcing by directly scattering or absorbing sunlight and indirectly change cloud properties though the formation of cloud condensation nuclei (Ramanathan et al., 2007).

Published by Copernicus Publications on behalf of the European Geosciences Union. 
With more than half of the world population living in cities, urban areas represent nowadays one of the major sources of fine anthropogenic aerosols at global scale, pointing out the need for a better characterization of these aerosols in the neighboring of their emission sources. Atmospheric pollution and exposure levels in the densely populated megacities (cities having more than 10 million of inhabitants) will be particularly high since these cities are generally confined to a relatively small area; they can represent a major fraction of emissions of a given country (Gurjar et al., 2004).

With a population of about 12 millions inhabitants (20\% of the French population), Greater Paris (France) is among the most populated megacities in Europe. Due to its favorable geographical situation (far from other big European cities and influenced very often by clean oceanic air masses), it may be considered as a good candidate for investigating the build-up of urban air pollution within temperate industrialized countries.

Particulate mass of fine aerosols $\left(\mathrm{PM}_{2.5}\right)$ is continuously monitored at several sites within Greater Paris since almost 8 years by the local air quality network (AIRPARIF), using a conventional on-line automatic system (R\&P TEOM; see Patashnik and Rupprecht, 1991). During the period 20002006, levels of $\mathrm{PM}_{2.5}$ in the region of Paris have shown rather stable yearly mean values ranging from 13 to $16 \mu \mathrm{g} \mathrm{m}^{-3}$ whereas primary pollutants monitored by AIRPARIF (carbon monoxide, sulfur dioxide, NO) have shown a net decrease during this period (http://www.airparif.asso.fr). Since the year 2007, yearly mean concentration of $\mathrm{PM}_{2.5}$ has substantially increased (up to $21 \mu \mathrm{g} \mathrm{m}^{-3}$ ), partly due to the use of a new measurement technique (R\&P TEOM-FDMS instrument) enabling a proper determination of the semi-volatile fraction of fine aerosols. Although this new method greatly improves the determination of $\mathrm{PM}_{2.5}$, it has also brought $\mathrm{PM}_{2.5}$ levels in the region of Paris closer to the $25 \mu \mathrm{g} \mathrm{m}^{-3}$ yearly mean targeted value recommended by Europe for 2010 (limit value for 2015). Efficient abatement policies aiming at reducing levels of $\mathrm{PM}_{2.5}$ in the region of Paris will have to be fed by preliminary $\mathrm{PM}_{2.5}$ source apportionment studies and exhaustive aerosol chemistry studies (chemical mass balance) allowing a better separation between local to continental aerosol sources.

Still only few studies are available on the chemical speciation of aerosols in the Paris region. They comprise preliminary characterizations of carbonaceous aerosols (Ruellan and Cachier, 2001), carbon and lead isotopes (Widory et al., 2004) and semi-volatile species (Favez et al., 2007). Time-limited information in the chemical composition of fine aerosols in Paris have been recently reported by Gros et al. (2007) but for a site impacted by traffic which may not be fully representative for the composition and levels of aerosols in the Paris urban background atmosphere. Modelling studies over Paris have been reported in literature but concerned mainly PM with A.D. $<10 \mu \mathrm{m}\left(\mathrm{PM}_{10}\right)$ or total sus- pended matter size fractions (Bessagnet et al., 2005; Hodzic et al., 2006). As a result, chemical composition of $\mathrm{PM}_{2.5}$ over the region of Paris remains poorly documented and regional model simulating $\mathrm{PM}_{2.5}$ concentrations and composition over this region poorly constrained.

In this context, time-resolved measurements of the major chemical constituents of fine aerosols may be particularly useful as they will offer a large database that can be used for model comparison. They may also help to better document large temporal variations in local emissions (such as traffic peaks generally observed at rush hours) as well as large diurnal fluctuation of the boundary height, thermodynamic equilibrium, ventilation, photochemistry, and air masses origin.

Hourly measurements of the main chemical constituents of $\mathrm{PM}_{2.5}$ are reported here for the first time for the city of Paris and cover a 3-week period during spring 2007. Hourly reconstruction of $\mathrm{PM}_{2.5}$ is calculated and compared with colocated continuous $\mathrm{PM}_{2.5}$ measurements corrected from filter sampling artifacts. Local and continental contributions to the major chemical constituents of $\mathrm{PM}_{2.5}$ are discussed in light of this time-resolved dataset, backtrajectory air masses analysis, comparison with volatile organic compounds (VOC) dataset and comparison with the aerosol chemistry outputs of a regional chemistry transport model (CHIMERE) which is currently used for air pollution forecast by AIRPARIF (www. airparif.asso.fr) and INERIS (www.prevair.org, Honoré et al., 2008).

\section{Experimental}

Atmospheric measurements were performed on the terraced roof (14 $\mathrm{m}$ above ground level) of the Laboratoire d'Hygiène de la Ville de Paris (LHVP; Paris, 13th district; $48^{\circ} 44^{\prime} 44^{\prime \prime}$ N, $2^{\circ} 21^{\prime} 35^{\prime \prime} \mathrm{E}$ ). This site corresponds to a monitoring station of AIRPARIF and is considered as being representative of Paris background air pollution (Favez et al., 2007). Results presented here were obtained from 23 May 2007 to 10 June 2007. A wide variety of VOC has been measured during this campaign and is reported in details by Gros et al. (2010) and Gaimoz et al. (2010). Meteorological parameters were monitored at the site every $5 \mathrm{~min}$ using a Campbell Scientific weather Station.

\subsection{Field instruments}

Reliable continuous (6-min time resolution) measurements of $\mathrm{PM}_{2.5}$ (nonvolatile plus semi-volatile) were performed by a Tapered Element Oscillating Microbalance (TEOM) Model 1400 from Rupprecht and Pataschnik equipped with a Sample Equilibration System (SES) and a Filter Dynamic Measurement System (FDMS, 8500 model series). This instrument delivers a concentration of semi-volatile material (SVM) in $\mathrm{PM}_{2.5}$ which is mainly made of ammonium nitrate for Paris background atmosphere (Favez et al., 
2007). Real-time PM measurements provided by the TEOM FDMS have shown to compare very well with other realtime measurement obtained from other analyzers taking into account SVM (Grover et al., 2005). A very good agreement was found between our TEOM-FDMS measurements performed at LHVP (13th district) with similar measurements performed by AIRPARIF in the center of Paris (1st district, les Halles), with $\mathrm{PM}_{2.5}(\mathrm{LHVP})=0.97 \cdot \mathrm{PM}_{2.5}$ (Les Halles) $+0.19 \mu \mathrm{g} \mathrm{m}^{-3} ; r^{2}=0.95 ; N=323$. This result indicates that our measurements are not significantly impacted by local contamination and may be representative for the Paris urban background atmosphere.

A mono-wavelength $(525 \mathrm{~nm})$ integrating nephelometer (ECOTECH, Model M9003) was operated in parallel with a $50 \%$ cut-off diameter inlet of $2.5 \mu \mathrm{m}$ (sharp Cut cyclone Model SCC 1.828, BGI Incorp., MA) and provided light scattering coefficient $\left(\sigma_{\mathrm{sp}}\right)$ measurements every $5 \mathrm{~min}$. A silicagel Diffusion Dryer (Model 3062, TSI Incorp., USA) mounted upstream of the nephelometer was used to keep relative humidity $(\mathrm{RH})$ inside the nephelometer below $30 \%$ in order to minimize the role of water uptake onto aerosols which is known to alter $\left(\sigma_{\mathrm{sp}}\right)$ measurements. More information on the operation, calibration, detection limit can be found in Sciare et al. (2008b).

Equivalent Black Carbon (EBC) measurements were obtained from 5-min integrated light absorption measurements performed by a seven-wavelength Aethalometer (Model AE31, Magee Scientific) running at 5 LPM and equipped with a $50 \%$ cut-off diameter of $2.5 \mu \mathrm{m}$ (R\&P, Albany, NY).

Hourly concentrations of elemental carbon (EC) and organic carbon (OC) in $\mathrm{PM}_{2.5}$ were obtained in the field from a semi-continuous ECOC field analyzer (Sunset Laboratory, Forest Grove, OR; Bae et al., 2004) running at 8 LPM. A denuder provided by the manufacturer was set upstream in order to remove possible adsorption of VOC onto the filter. Measurement uncertainty given by the ECOC analyzer is poorly described in literature and an estimate of $20 \%$ for this uncertainty was taken here following Peltier et al. (2007).

\subsection{Filter sampling and chemical analyses}

Fine (A.D. $<2.5 \mu \mathrm{m}$ ) aerosols were collected continuously on 25-mm diameter pre-fired quartz filters (QMA) at a flowrate of $6.8 \pm 1.5 \mathrm{LPM}$ and using the same sharp cut cyclone as for the ECOC analyzer (Very Sharp Cut Cyclone (VSCC), BGI Inc., Waltham, MA). A denuder identical to the one used upstream of the ECOC analyzer was set between the cyclone and the filter holder in order to minimize artefacts due to VOC adsorption onto the filter matrix. The filter sampling interval was typically of the order of $12 \mathrm{~h}$. A total of 36 filter samples were then collected during the campaign.

Half of the 25-mm diameter QMA filters were analyzed for their EC and OC content using a thermo-optical carbon analyzer (ECOC Lab Instrument, Sunset Lab.) implemented with the NIOSH thermal program (Birch and Cary, 1996).
The uncertainty given by the manufacturer for $\mathrm{EC}$ and $\mathrm{OC}$ measurements is of $0.2 \mu \mathrm{gC} \mathrm{cm}{ }^{-2} \pm 5 \%$. A total of 7 blanks were taken in the field covering the duration of the campaign and showed non detectable amounts of EC. An average value of $0.78 \pm 0.15 \mu \mathrm{gC} \mathrm{cm}{ }^{-2}$ for OC blanks was calculated and subtracted from the OC values obtained in the field.

Water-soluble organic carbon (WSOC) and ion analyses were achieved on the second half of the QMA quartz filters. WSOC measurements were performed using a total organic carbon analyzer (TOC, Model Sievers 900, Ionics Ltd, USA) in which ammonium persulphate and UV light (185 and $284 \mathrm{~nm}$ ) are used for the oxidation and the quantification of organic carbon. Information on filter extraction protocol, detection limit, and calibration for WSOC analysis can be found in Sciare et al. (2008a). Concentrations of WSOC were corrected from blank filters taken in the field showing an average WSOC concentration of $0.54 \pm 0.18 \mu \mathrm{gC} \mathrm{cm}{ }^{-2}$. Ion composition (anions, cations) of the filter samples were also determined following the extraction and analytical protocol described in Sciare et al. (2005).

\subsection{Validation of $\mathrm{OC}$ and EC field measurements}

The consistency of our field measurements of EC and OC was checked by comparing results obtained by the ECOC field instrument, the aethalometer, and filter sampling. Hourly BC data obtained optically by the ECOC field instrument were compared with the equivalent $\mathrm{BC}$ data (EBC) given by the aethalometer when both instruments were running in parallel (23 May-10 June). A very good agreement was found between the 2 datasets $\left(r^{2}=0.94 ; N=417\right)$ with a slope close to one (0.96). Comparison between EC concentrations measured in the field (ECOC field instrument) with EC measurements obtained from filter sampling showed also a good agreement $\left(r^{2}=0.79 ; N=34\right)$ with a slope also close to 1 (1.06). Similarly, comparison between OC concentrations measured in the field (ECOC field instrument) with OC measurements obtained from filter sampling showed a good agreement $\left(r^{2}=0.76 ; N=34\right)$ with a slope close to $1(1.01)$. However, a significant intercept of $3.03 \mu \mathrm{gC} \mathrm{m}^{-3}$ was found between these 2 datasets, pointing out a constant overestimation of OC concentration levels obtained in the field. Temporal variation of the 2 dataset is reported in Fig. 1 and clearly shows the constant offset of about $3 \mu \mathrm{gC} \mathrm{m}^{-3}$ for the OC derived from the ECOC field instrument. Such an offset can also be defined as a constant blank value in the sunset field instrument and has been widely reported in literature, usually associated with a breakthrough of the VOC denuder (Bae et al., 2004; Arhami et al., 2006; Polidori et al., 2006). The influence of this offset has been investigated in a more systematic way by Offenberg et al. (2008) who have shown that this offset (ranging from $0.5 \mu \mathrm{gC}$ to $2.0 \mu \mathrm{gC}$ ) was strongly dependent on the sampled air volume; more air being needed to minimize the offset. Our blank value (offset) due to VOC adsorption is calculated here as $1.30 \mu \mathrm{gC}$ and falls within 


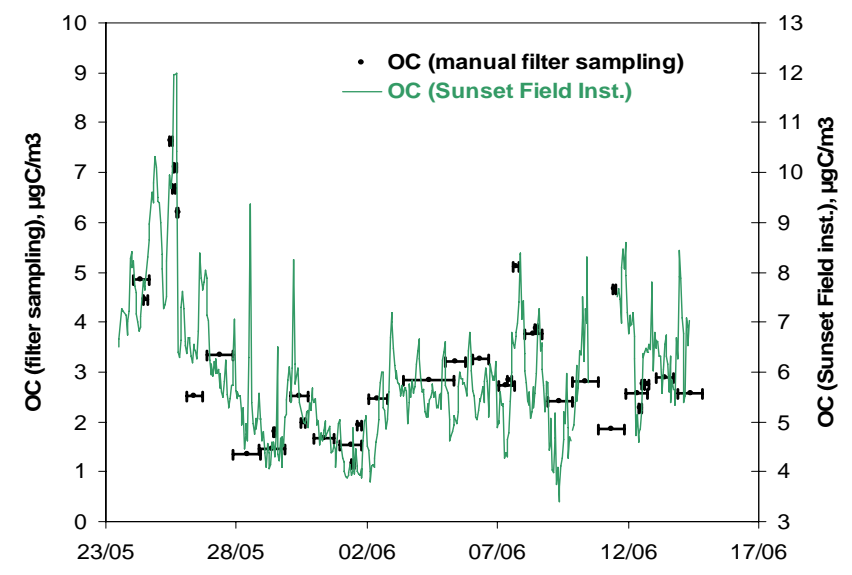

Fig. 1. Hourly OC concentrations from the semi-continuous OCEC sunset field instrument (uncorrected for the offset of $3.03 \mu \mathrm{gC} \mathrm{m}^{-3}$ ) and OC concentrations from the manual filter sampling. Horizontal bars stand for the duration of the filter sampling.

the range given previously. Field OC data discussed in the following were then corrected from this constant value of $3.03 \mu \mathrm{gC} \mathrm{m}^{-3}$. Particulate organic matter (POM) concentrations reported in the following were calculated using an OC to POM conversion factor of 1.6 as proposed by Turpin and Lim (2001) for urban aerosols.

\subsection{Determination of ion concentrations and reconstruction of $\mathbf{P M}_{2.5}$}

Hourly ion measurements were not available during this campaign but can be estimated using the reconstruction of the light scattering coefficient following the methodology reported in detail by Sciare et al. (2008b). Briefly, a simple model assuming an external mixing of the particles with constant dry mass scattering efficiencies and constant aerosol types (Malm et al., 1994, 2000) can be used here to reconstruct the light scattering coefficient $\left(\sigma_{\mathrm{sp}}\right)$, following the equation:

$$
\begin{aligned}
\sigma_{\text {sp }} & =\alpha_{\text {ions }} f(\mathrm{RH})\left(\left[\left(\mathrm{NH}_{4}\right)_{2} \mathrm{SO}_{4}\right]+\left[\mathrm{NH}_{4} \mathrm{NO}_{3}\right]\right) \\
& +\alpha_{\text {POM }}[\mathrm{POM}]+\alpha_{\text {sea salt }}[\text { sea salt }]+\alpha_{\text {dust }}[\text { dust }]
\end{aligned}
$$

Where $\alpha_{X}$ stands for the mass scattering efficiency of the chemical species $[X]$. It is assumed here that $\left(\mathrm{NH}_{4}\right)_{2} \mathrm{SO}_{4}$ and $\left(\mathrm{NH}_{4}\right) \mathrm{NO}_{3}$ have a similar mass scattering efficiency $\left(\alpha_{\text {ions }}\right)$ assigned to be $3 \mathrm{~m}^{2} \mathrm{~g}^{-1}$, which is an average of values commonly reported in literature (Sciare et al., 2005 and references therein). The mass scattering efficiency of POM $\left(\alpha_{\mathrm{POM}}\right)$ is taken equal to $4 \mathrm{~m}^{2} \mathrm{~g}^{-1}$ (Malm et al., 1994). Since our nephelometer measurements were not significantly affected by water uptake onto aerosols, a constant enhancement factor, $f(\mathrm{RH})$, equal to 1 is taken here.

Non sea salt calcium (nss-Ca) and sodium can be used here as tracers for dust and sea salt aerosols, respectively, and were analyzed by ion chromatography (Sect. 2.2). Very

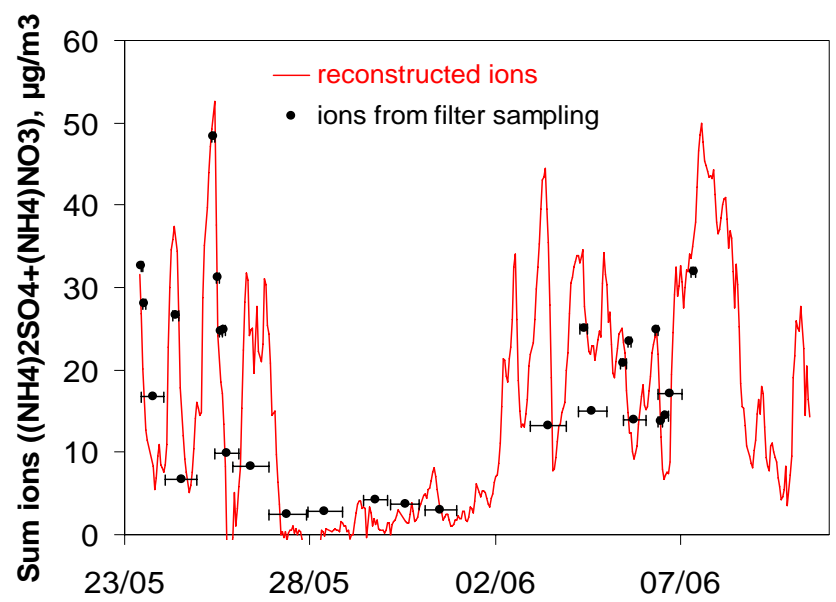

Fig. 2. Hourly reconstructed ions concentrations derived from Eq. (2) and ions concentrations (ammonium nitrate and ammonium sulfate) from manual filter sampling. Horizontal bars stand for the duration of the filter sampling.

low concentrations of sea salt and dust aerosols (typically below $1 \mu \mathrm{g} \mathrm{m}^{-3}$ ) are then estimated here in fine aerosols, using a calcium-to-dust ratio of 0.10 (Sciare et al., 2005; Guinot et al., 2007) and a sodium-to-sea salt ratio of 0.306 (Ohta and Okita, 1990). The contribution of dust and sea salt aerosols to the light scattering coefficient (Eq. 1) is then neglected here due to their low concentrations and due to their low mass scattering efficiencies.

Based on these assumptions, Eq. (1) can be re-written as:

$$
\begin{aligned}
{[\text { ions }] } & =\left[\left(\mathrm{NH}_{4}\right)_{2} \mathrm{SO}_{4}\right]+\left[\left(\mathrm{NH}_{4}\right) \mathrm{NO}_{3}\right] \\
& \left.=\left(\sigma_{\mathrm{sp}}-4 \times[\mathrm{POM}]\right) / 3\right)
\end{aligned}
$$

Hourly concentrations of ions can be derived from this Eq. (2) for the whole period of measurement (23 May-10 June). An overall uncertainty associated with this ion calculation is estimated to be of the order of $30 \%$ (Sciare et al., 2008b) and takes into account uncertainties associated with the field instruments, OC-to-POM conversion factor, and light scattering efficiencies $\left(\alpha_{\text {ions }}\right.$ and $\left.\alpha_{\text {POM }}\right)$. Despite this important uncertainty, comparison of this ion dataset with filter data ion measurements (sum of ammonium, nitrate, sulfate) obtained in parallel and depicted in Sect. 2.2 shows very satisfactory results (slope of 1.03 and $r^{2}=0.76$; $N=27$ ). Temporal variations of reconstructed ions concentrations (derived from Eq. 2) and measured ions concentrations (obtained with the filter sampling) are reported in Fig. 2 for comparison purposes. The good agreement observed in these 2 datasets further validates the indirect method used here to calculate hourly concentration of ions (ammonium sulfate + ammonium nitrate).

These concentrations of ions (derived from Eq. 2) were summed with concentrations of POM and EC (derived from the ECOC field instrument) in order to reconstruct $\mathrm{PM}_{2.5}$ concentrations every hour. Comparison of this reconstructed 


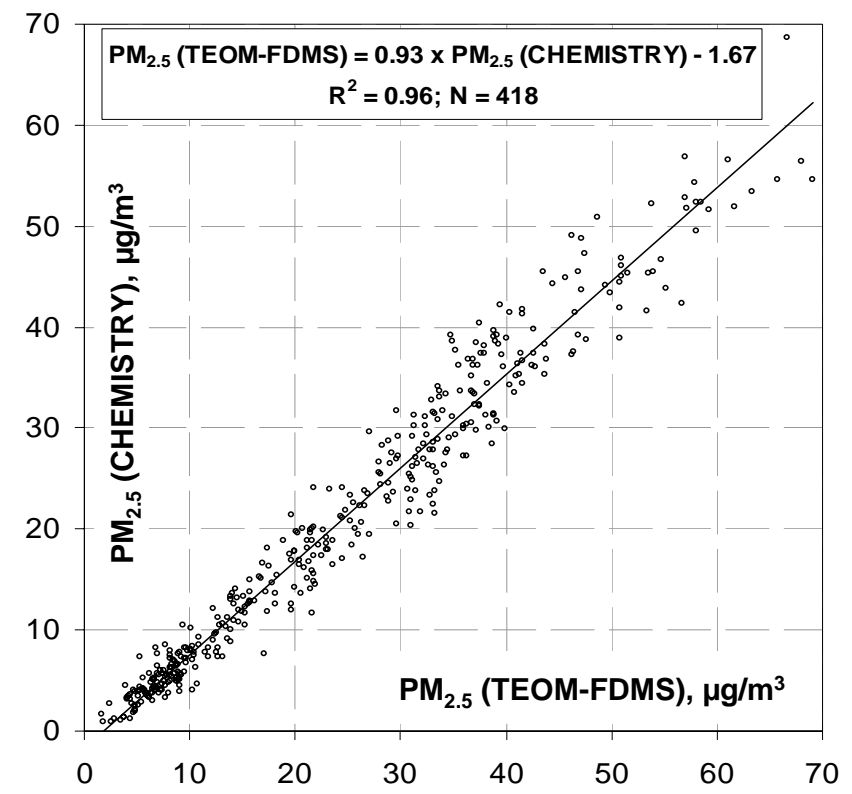

Fig. 3. Comparison between hourly $\mathrm{PM}_{2.5}$ concentrations measurements performed by TEOM-FDMS and hourly $\mathrm{PM}_{2.5}$ concentrations reconstructed from the chemical analyses by summing EC, $\mathrm{POM}$, and ions.

$\mathrm{PM}_{2.5}$ (noted as $\mathrm{PM}_{2.5}$ (CHEMISTRY)) with $\mathrm{PM}_{2.5}$ concentrations obtained independently with the TEOM-FDMS monitor is reported in Fig. 3. A very good agreement can be observed here between these two datasets $\left(r^{2}=0.96\right.$; $N=418)$ with a slope close to one (0.93) and an intercept close to zero $\left(-1.7 \mu \mathrm{g} \mathrm{m}^{-3}\right)$. This good accordance between measured and chemically reconstructed $\mathrm{PM}_{2.5}$ demonstrates again the consistency of the hypotheses used to calculate hourly concentrations of ions and those to reconstruct $\mathrm{PM}_{2.5}$ concentrations.

It can be also noted here that ions and carbonaceous aerosols can be considered as the two major components of Paris fine aerosols during springtime, in agreement with the study by Gros et al. (2007) who have reported that these chemical species (ions and carbonaceous aerosols) contributed to almost $95 \%$ of the $\mathrm{PM}_{2.5}$ in Paris during springtime.

\section{Model Description}

The model used in this study is the Eulerian regional chemistry-transport model CHIMERE in its version V2008b (see http://www.lmd.polytechnique.fr/chimere/). The initial gas phase chemistry scheme has been described by Schmidt et al. (2001) and Vautard et al. (2001), the aerosol modules by Bessagnet et al. (2004 and 2008). The model has been largely applied for continental scale air quality forecast (Honoré et al., 2008; http://www.prevair.org), and simulations, including sensitivity studies, with respect to biogenic emissions
(Curci et al., 2009) and inverse emission modeling (Konovalov et al., 2006). The model has been also extensively used to simulate gas phase pollution levels over the Paris region (e.g., Vautard et al., 2001; Beekmann et al., 2003; Derognat et al., 2003; Deguillaume et al., 2007 and 2008), and on several occasions particulate matter (e.g. Bessagnet, 2005; Hodzic et al., 2006).

In this work, the model is set up on three successively nested grids: a continental domain $\left(35^{\circ}-57.5^{\circ} \mathrm{N} ; 10.5^{\circ} \mathrm{W}-\right.$ $22.5^{\circ} \mathrm{E}$ ) with $0.5^{\circ}$ resolution, a regional domain covering Northern France with $9 \mathrm{~km}$ resolution and a more refined local/urban domain covering Ile-de-France region with a $3 \mathrm{~km}$ horizontal resolution. In the vertical, eight hybrid-sigma vertical layers extend up to $500 \mathrm{hPa}$, the first layer extends up to about $40 \mathrm{~m}$.

Tropospheric photochemistry is represented using the MELCHIOR chemical mechanism (Lattuati, 1997) that includes 120 reactions and 44 prognostic gaseous species. All major aerosol components are considered, namely primary organic (POA) and black carbon (BC), other unspecified primary anthropogenic components, wind-blown dust, sea salt, secondary inorganics (sulfate, nitrate and ammonium) as well as secondary organic aerosols from anthropogenic and biogenic origin, and particulate water. The model does not provide information on hydrophobic/hydrophilic fractions of organic aerosols. A sectional size distribution over 8 size bins geometrically spaced from $40 \mathrm{~nm}$ to $10 \mu \mathrm{m}$ in physical diameter is chosen. The thermodynamic partitioning of the inorganic mixture (i.e. sulfate, nitrate, and ammonium) is computed using the ISORROPIA model (Nenes et al., 1998). Partitioning of semi-volatile OC of anthropogenic and biogenic origin is governed by a SOA formation scheme elaborated by Pun and Seigneur (2006) and adapted by Bessagnet et al. (2008). The dynamical processes influencing aerosol growth such as nucleation, coagulation and absorption of semi-volatile species are included in the model as described by Bessagnet et al. (2004). Heterogeneous chemical processes onto particles and a simplified sulfur aqueous chemistry are also considered. Dry and wet deposition for all gaseous and aerosol species are computed as a function of the friction velocities and stability of the lowest model layer (Wesely, 1988), and as a function of grid-averaged precipitation rates and cloud water content (Tsyro, 2002). Clear sky photolysis rates are calculated off-line based on the TUV model (Madronich et al., 1998), and they are modified when in the presence of clouds. The numerical method for the temporal solution of the stiff system of partial differential equations is adapted from the second order TWOSTEP algorithm originally proposed by Verwer (1994), and is set-up using a time step of $2.5 \mathrm{~min}$ for chemistry.

Meteorological input is provided by PSU/NCAR MM5 model (Dudhia, 1993) run with three nested grids at $45 \mathrm{~km}$ (European domain), $15 \mathrm{~km}$ (North-West Europe and $5 \mathrm{~km}$ (Central France) resolution. In the vertical, 23 sigma layers extend up to $100 \mathrm{hPa}$. Meteorological fields are interpolated 
on the nested CHIMERE with horizontal and vertical resolution given above (Valari and Menut, 2008). MM5 is forced by the NCEP FNL (Final) Operational Global Analysis data from the Global Forecast System (GFS) operated four times a day in near-real time by the American National Centers for Environmental Prediction (NCEP), using the grid nudging (grid FDDA) option implemented within MM5. Anthropogenic gaseous and particulate emissions are derived from EMEP annual totals (http://www.ceip.at/ emission-data-webdab/) and scaled to hourly emissions applying temporal profiles provided by IER (Friedrich, 1997). For the nested Northern France and Ile-de-France grid, refined emissions have been elaborated by the 6 ESMERALDA project partners that are, AIRPARIF, AIR NORMAND, ATMO PICARDIE, ATMO CHAMPAGNE-ARDENNE, ATMO NORD PAS-DE-CALAIS and LIG'AIR. For gas phase species, they stem from a specific cadastre for Ilede-France and Northern France (Elaboration of an interregional emissions inventory for the modeling platform of cartographic previsions ESMERALDA - 2005). For particulate matter emissions, a downscaling algorithm based on CORINE land-use data starting from EMEP annual totals is used to obtain spatially refined data. Splitting of $\mathrm{PM}_{2.5}$ emissions is performed using the emission inventory of Laboratoire d'Aérologie (Junker and Liousse, 2008). Biogenic emissions are provided by the MEGAN data base (Guenther et al., 2006). LMDz-INCA monthly mean concentrations are used as boundary conditions (Hauglustaine et al., 2004).

\section{Results and discussion of experimental data}

A brief description of the temporal variations of $\mathrm{PM}_{2.5}$, ion species, and carbonaceous aerosols is presented here, based on air masses origin (backtrajectory analysis). Contributions of local/continental emissions are then discussed based on the analysis of mean diurnal variations of each aerosol component, comparison with complementary VOC measurements and $\mathrm{PM}_{2.5}$ measurements performed in the neighboring regions of Paris.

\subsection{Backtrajectory analysis}

Four-day back trajectories were calculated using the Hysplit Dispersion Model (Hybrid Single - Particle Lagrangian Integrated Trajectory; Draxler and Rolph, 2003; Rolph, 2003) with a $500 \mathrm{~m}$ height at the end point (sampling site). According to the air masses origin, the field campaign could be divided into the 3 distinct periods displayed in Fig. 4. The first period of the campaign (4 days: 23 November 00:0027 November 00:00 LT) was characterized by a high pressure system associated with air masses moving slowly and originating from Northern-Western Europe (Rhine-Ruhr region). During this period residence time of air masses above continental areas was typically of $72 \mathrm{~h}$ or more. The sec-

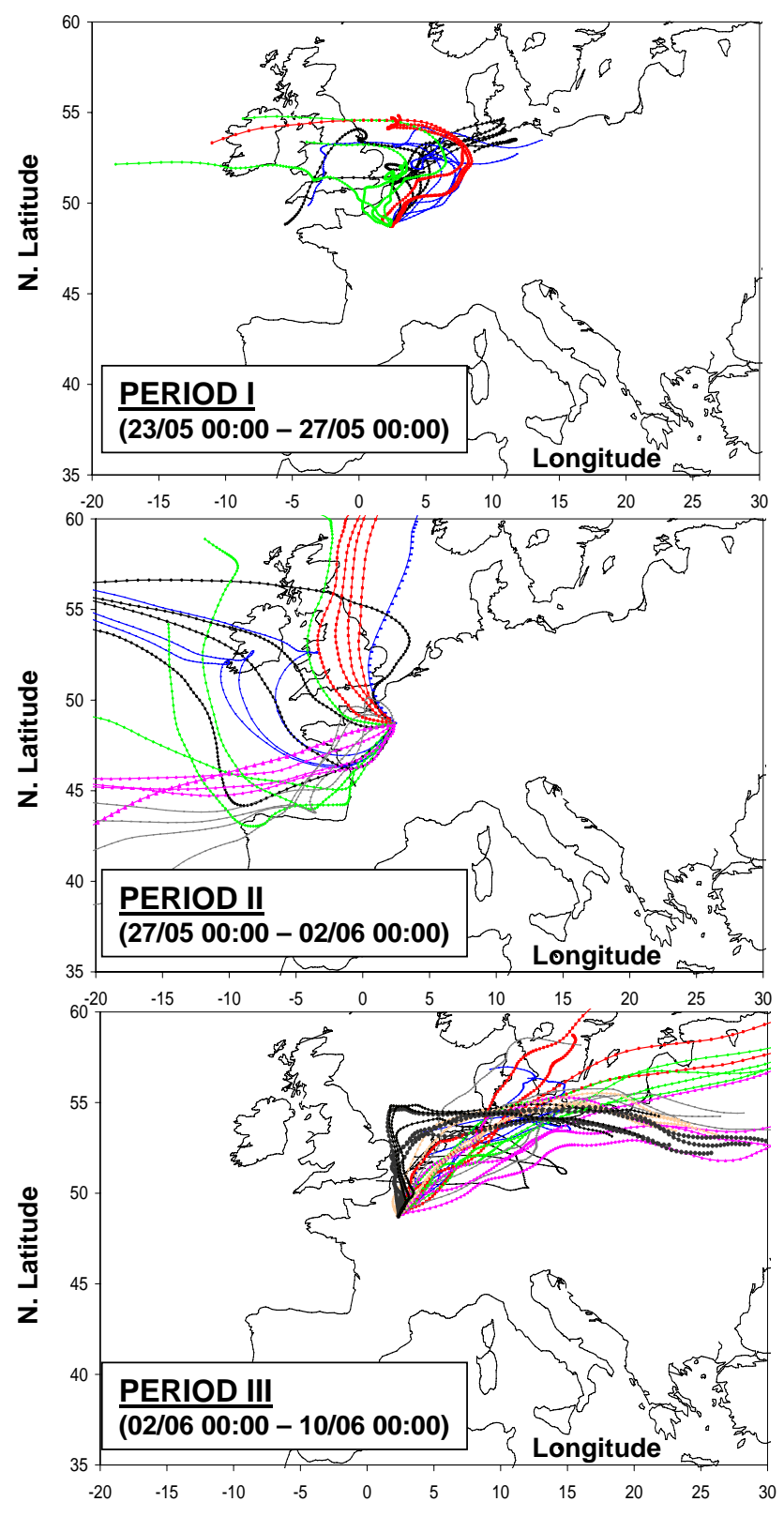

Fig. 4. 4-day backtrajectories ending at Paris (LHVP monitoring station; $500 \mathrm{~m}$ above ground level) and calculated every $6 \mathrm{~h}$ for the periods I (A), period II (B), and period III (C) depicted in Sect. 4.1.

ond period (7 days: 27 November 00:00-2 June 00:00 LT) was characterized by the presence of frontal (low pressure) systems and moderate western winds. Air masses originated mainly from the Atlantic Ocean during this period, and the residence time of air masses above the continental surface was less than $10 \mathrm{~h}$. The air masses origin observed during the third period (9 days: 2 June 00:00-10 June 12:00 LT) showed a pronounced North Eastern European influence. The residence time of these air masses above the continent was again typically more than $72 \mathrm{~h}$. 


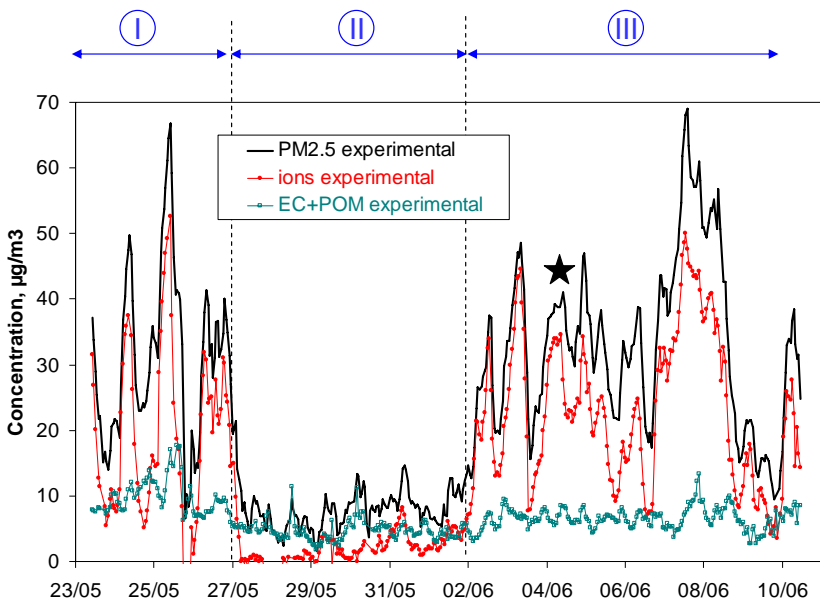

Fig. 5. Hourly $\mathrm{PM}_{2.5}$ concentrations measured by TEOM-FDMS, fine carbonaceous aerosols $(\mathrm{EC}+\mathrm{POM})$ and reconstructed fine ions (ammonium nitrate + ammonium sulfate). Periods I and III were influenced by continental (European) air masses; period II was influenced by clean marine air masses. The black star corresponds to the pollution episode (plume case study) depicted in Sect. 5.1.

\subsection{Temporal variation of the major chemical constituents of fine aerosols}

Hourly concentrations of $\mathrm{PM}_{2.5}$ (TEOM-FDMS), ions (sum of ammonium nitrate and ammonium sulfate calculated as described in the previous section) and carbonaceous aerosols $(\mathrm{EC}+\mathrm{POM})$ are reported in Fig. 5 for the 3-week duration of the campaign. The periods I, II, and III previously described from backtrajectory analysis are also reported in this Figure. An average $\mathrm{PM}_{2.5}$ concentration of $24.3 \mu \mathrm{g} \mathrm{m}^{-3}$ was calculated for this campaign which is close to the yearly (2007) $\mathrm{PM}_{2.5}$ concentration of $21 \mu \mathrm{g} \mathrm{m}^{-3}$ calculated for the urban area of Paris and illustrates that this campaign did not undergo unusual high levels of $\mathrm{PM}_{2.5}$ compared to the rest of the year.

The first and third periods (continental air masses from North-Western Europe) were characterized by a strong variability in $\mathrm{PM}_{2.5}$, with concentrations ranging from 5 to almost $70 \mu \mathrm{g} \mathrm{m}^{-3}$, with intense but time-limited peak values and mean concentrations higher than the $25 \mu \mathrm{g} \mathrm{m}{ }^{-3} \mathrm{EU}$ recommended limit value. Interestingly, all the sharp maxima observed in $\mathrm{PM}_{2.5}$ were entirely related to similar maxima in ions with concentration levels up to $50 \mu \mathrm{g} \mathrm{m}^{-3}$. This strong covariation observed between $\mathrm{PM}_{2.5}$ and ions observed is illustrated by the high correlation coefficient calculated between these 2 fractions $\left(r^{2}=0.93\right)$. During the periods I and III, ions contributed to almost $75 \%$ of the fine aerosol mass.

These results clearly show that the highest levels of $\mathrm{PM}_{2.5}$ (and ions) were observed during the periods with continental air mass advection, possibly suggesting a long range transport origin for ion species. Such a continental (European) contribution to PM concentrations and composition in Paris
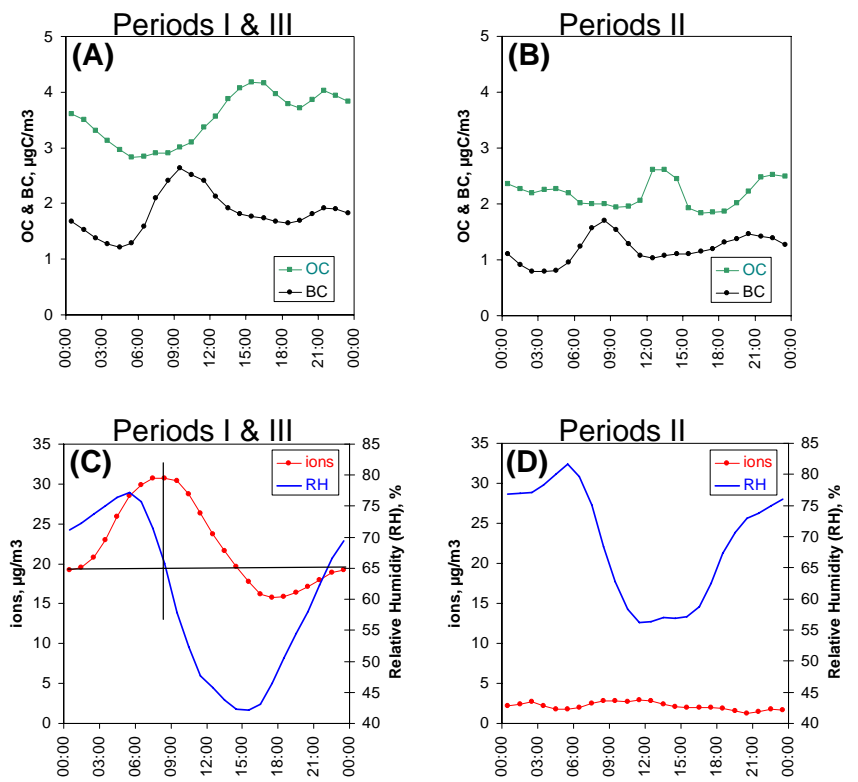

Fig. 6. Diurnal variations of $\mathrm{BC}$ and $\mathrm{OC}$ concentrations for periods I and III (A) and period II (B). Diurnal variations of ions concentrations (derived from Eq. 2) and relative humidity (RH) for periods I and III (C) and period II (D).

has to be investigated more thoroughly against a larger number of observations as it may have important implications for local abatement strategies.

It is interesting to note here that the variability of carbonaceous aerosols is completely disconnected from that of ions. Their levels were less variable during the campaign, ranging from 5 to $10 \mu \mathrm{g} \mathrm{m}^{-3}$. Their contribution to $\mathrm{PM}_{2.5}$ is particularly weak during the periods I and III when $\mathrm{PM}_{2.5}$ is higher than $25 \mu \mathrm{g} \mathrm{m}^{-3}$. On the other hand, they represent as much as $75 \%$ of $\mathrm{PM}_{2.5}$ during the period II (marine air masses) which is characterized by low levels of $\mathrm{PM}_{2.5}$ (and ions).

\subsection{Diurnal variations of ions, and carbonaceous aerosols}

In order to better discriminate between local and continental emissions, mean diurnal variations of the $\mathrm{BC}, \mathrm{OC}$, and ions (as shown in Eq. 2) were calculated and reported in Fig. 6 for the periods I\&III (continental air masses) and the period II (marine air masses). Aerosol species originating from far away are expected to present less variable diurnal variations in contrast with aerosols of local origin which should be more dependent on emission temporality, photochemical processes and/or thermodynamic equilibrium. As depicted in Fig. 6, the BC diurnal profile shows a clear morning peak (08:00-10:00) and a second one (less pronounced) end of the day (20:00-22:00). This type of profile does not depend on air mass origin (continental/marine) and can be attributed to local traffic emission peaks at rush hours. Although OC concentrations during periods I\&III are almost twice as large as 
OC concentrations during period II, the mean diurnal profile of OC remains quite similar for all periods with a first maximum during the afternoon (probably linked to photochemical processes) and a second one concomitant with the evening $\mathrm{BC}$ maximum. These results show that local patterns (traffic, photochemistry) can be considered as key factors controlling the diurnal variations of $\mathrm{BC}$ and $\mathrm{OC}$, although systematically higher concentrations are observed for these species during periods with continental air masses.

As shown in Fig. 6, the diurnal variability of ions for continental air masses is important with a constant rise during nighttime (from 00:00 to 08:00) when local (traffic) emissions are at their lowest level. This increase is followed by a regular decrease observed during daytime (from 08:00 till 17:00). This pattern is somewhat unexpected if we consider that ions originate from long range transport. On the other hand, one must keep in mind that semi-volatile ammonium nitrate is a major component of these ions and should be affected by local thermodynamic equilibriums. This is confirmed by the diurnal variations of Relative Humidity $(\mathrm{RH})$ which shows values below 65\% during daytime (from 08:00 till 22:00), but larger values during nighttime. This RH value of $65 \%$ stands for the typical limit value above which an inorganic salt (ammonium sulfate, ammonium nitrate) becomes hydrated (Wexler and Clegg, 2002). Then it can be reasonably hypothesized here that the diurnal profile of ions (during continental air masses periods) is mainly governed by the diurnal variation of semi-volatile ammonium nitrate; accumulating during nighttime under favorable thermodynamic conditions (wet aerosols) and evaporating during daytime when aerosols become dry. This RH dependence of ammonium nitrate has been often referred in literature (Ansari and Pandis, 1999; Charron et al., 2004; Sciare et al., 2007). Note also that formation of ammonium nitrate of local/regional origin cannot be excluded here as it will be shown from modeling results in Sect. 5.3.

\subsection{Comparison with $\mathrm{PM}_{2.5}$ measurements performed in the neighboring regions of Paris}

In order to better infer local versus continental contributions to $\mathrm{PM}_{2.5}$ levels observed in Paris, the $\mathrm{PM}_{2.5}$ concentration levels at 3 different sites, Paris - LHVP (this study), Bethune (suburban monitoring station from the ATMO PASDE-CALAIS air quality network), and St Jean (suburban monitoring station from the LIG'AIR air quality network) have been reported in Fig. 7. As displayed in this Figure, the temporal variations of $\mathrm{PM}_{2.5}$ at these sites show common patterns, with a more pronounced contrast between marine/continental air masses for the Paris-LHVP and St Jean stations than for the Bethune site. Interestingly, most of the sharp $\mathrm{PM}_{2.5}$ peaks observed in Paris are also seen at the other stations with a time lag of few hours suggesting large scale rather than local sources for these maxima. A more quantitative comparison can be performed for the 2 closest stations
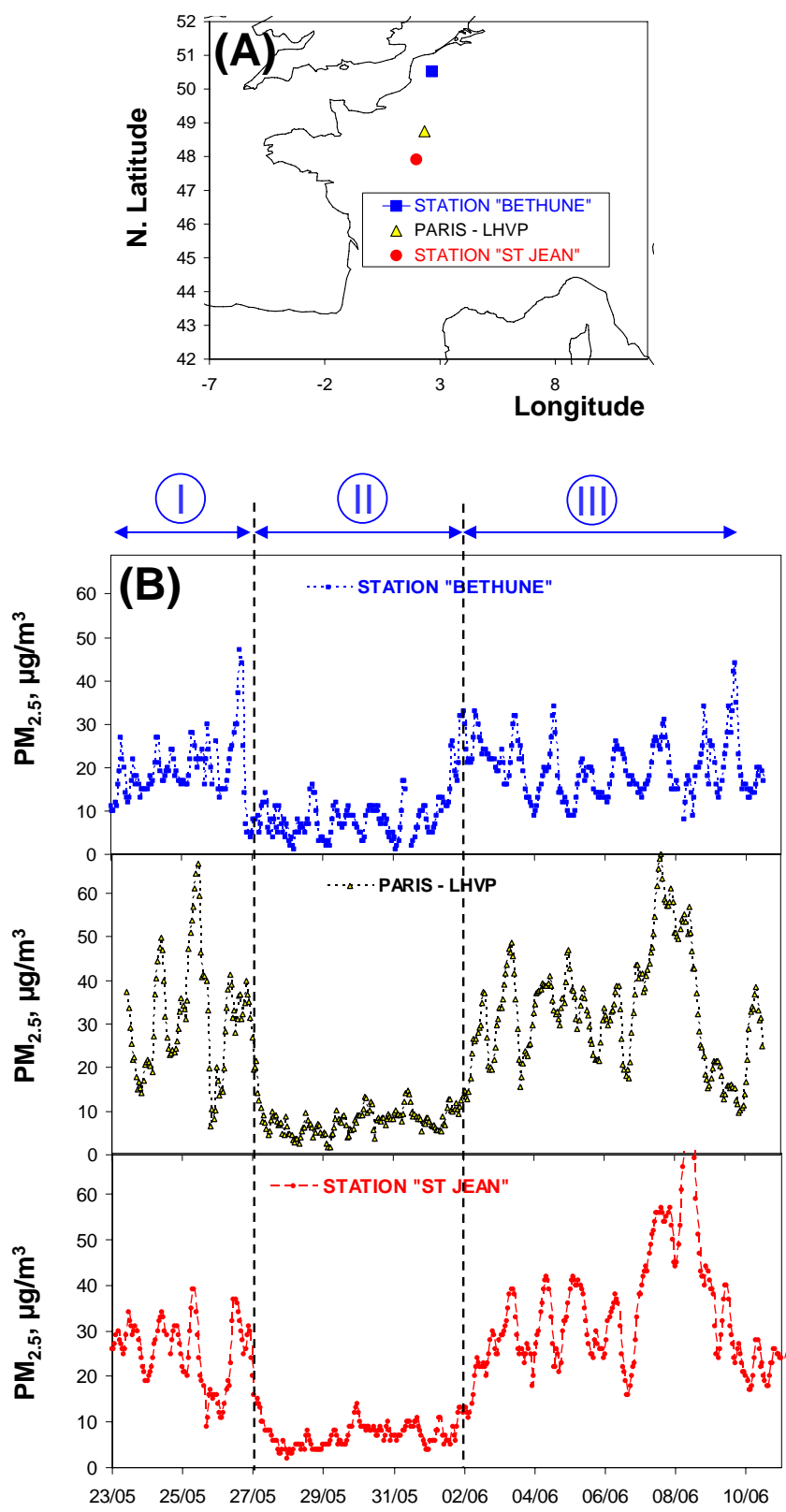

Fig. 7. (A) Location of 3 ground stations with $\mathrm{PM}_{2.5}$ (TEOMFDMS) measurements in the neighboring regions of Paris. (B) Temporal variation of $\mathrm{PM}_{2.5}$ at these 3 stations. Periods noted I, II, and III correspond to those reported in Sect. 4.1.

(Paris-LHVP and St Jean, located at about $100 \mathrm{~km}$ distance). A relatively good agreement is observed for these 2 datasets $\left(r^{2}=0.68\right)$ when a time lag of $3 \mathrm{~h}$ is applied for the St Jean $\mathrm{PM}_{2.5}$ dataset.

From these observations, it can be reasonably hypothesized that a significant fraction of ion species observed in Paris during our study was transported (or formed during their transport) from continental Europe and was spread over large areas. This hypothesis is consistent with the EMEP 
inventories which show large emission areas over NorthWestern Europe for the gas precursors of ion species $\left(\mathrm{NH}_{3}\right.$, $\mathrm{NO}_{\mathrm{x}}, \mathrm{SO}_{2}$ ). It is also consistent with the fact that ion production requires atmospheric ageing to occur and subsequently is expected to show higher values downwind of the emission sources of their gas precursors.

\subsection{Comparison with co-located VOC source apportionment results}

It is interesting to note here that the influence of air masses origin on ion concentration levels is also observed for oxygenated VOCs such as acetone and methanol which show much higher baseline levels in continentally influenced than in oceanic air (Gros et al., 2010) (data not shown here). Acetone has an intermediate lifetime of about one month with primary sources mainly of biogenic origin but has also an important contribution from secondary sources (namely oxidation of non methane hydrocarbon, NMHC). The good accordance between ion species and oxygenated VOCs points to the fact that both fractions are photochemically produced.

As shown in Fig. 5, the fact that carbonaceous aerosols are much less dependent on air mass origin suggests that the main sources of these particles may be more local (i.e. within the Greater Paris agglomeration). This is consistent with the diurnal variation of BC and OC (Fig. 6). This is also in line with the results obtained from NMHC measurements (e.g. benzene, toluene, C8- and C9-aromatics) performed in parallel showing a weak influence of air mass origin, and a major local source (vehicle exhaust) (Gaimoz et al., 2010).

\section{Model comparison and simulation of continental versus local contributions}

A preliminary interpretation of the temporal variability of experimental data $\left(\mathrm{PM}_{2.5}\right.$, ion species, and carbonaceous aerosols) has been proposed in the previous section and has shown that the maxima of $\mathrm{PM}_{2.5}$ observed during our study were mainly due to ion species that could originate from North-Western Europe, spreading over large areas during their transport. The role of local and continental emissions is still difficult to evaluate with our present dataset. Although there are some indications that long range transport may significantly contribute to the levels of ions in Paris, regional pollution build-up and its contribution to the levels of ions (and carbonaceous aerosols) cannot be ruled out. Changes in meteorological conditions (ventilation, boundary height, thermodynamic equilibrium) and in photochemistry that occur between marine and continental air masses may also significantly affect the levels and composition of $\mathrm{PM}_{2.5}$ in a way that is hardly predictable using solely experimental dataset. The apparent weak contribution of European carbonaceous aerosols compared to local emissions requires also more attention. Discrimination between primary and secondary or- ganic aerosol may be needed here to better identify the origin of this carbonaceous matter.

In order to better distinguish the local from the continental contribution to $\mathrm{PM}_{2.5}$ concentrations and chemical composition, a comprehensive chemical transport model (CHIMERE) is used here and its results are compared with experimental data. A first qualitative approach of local/continental influences is presented for two consecutive pollution events. Model outputs are then tested against observations for $\mathrm{PM}_{2.5}$, ions, and carbonaceous aerosols (EC+POM). Different scenarios are investigated using CHIMERE, "switching" OFF consecutively the local and EU sources of gas precursors of ions and carbonaceous aerosols. At last, a focus is put on carbonaceous aerosols; different experimental methods are used to discriminate between primary and secondary organic aerosols and are then compared with model output in order to depict their local-tocontinental contribution.

\subsection{Plume case study}

Two consecutive (partly overlapping) pollution events modeled by CHIMERE for 4 June are displayed in Fig. 8; a first one for fine nitrate (3 June 20:00 LT-4 June 12:00 LT) and a second for fine sulfate (4 June 04:00 LT-5 June 01:00 LT).

The first episode (Fig. 8a) shows a nitrate plume progressing from Benelux to the Paris region. It corresponds to the period noted with a black star in Fig. 5. Inspection of gaseous precursor emissions suggests that ammonium nitrate formation occurs as a result of strong $\mathrm{NO}_{\mathrm{x}}$ emissions over the Rhine-Ruhr region oxidizing to $\mathrm{HNO}_{3}$, and mixing with air masses having encountered strong ammonia emissions over the Netherlands and Belgium.

The second episode (Fig. 8b) occurs a day later and shows a burst in concentration of fine sulfate over a large area (Rhine-Rhur region, North of France, Central England) within few hours (4 June in the morning). Most of this burst corresponds to intense in-situ photochemical oxidation of $\mathrm{SO}_{2}$. It should be noted that the region of Paris is located at the limit of the geographic zone where these two events occurred which may partly explain the time-limited duration of these episodes over the region (Fig. 5). Note also that these two events simulated by CHIMERE highlight the major role of gas precursors $\left(\mathrm{NO}_{\mathrm{x}}, \mathrm{SO}_{2}\right)$ and their potential to be transported and converted into fine nitrate and sulfate far from their emission sources.

\subsection{Temporal variation of experimental and modelled fine aerosol constituents}

Comparison between modelled and experimentally determined concentrations of $\mathrm{PM}_{2.5}$, ions and carbonaceous matter is reported in Fig. 9. To our best knowledge, this is the first time that the CHIMERE model is tested against 
(A) Nitrate in $\mathrm{PM}_{2.5}$

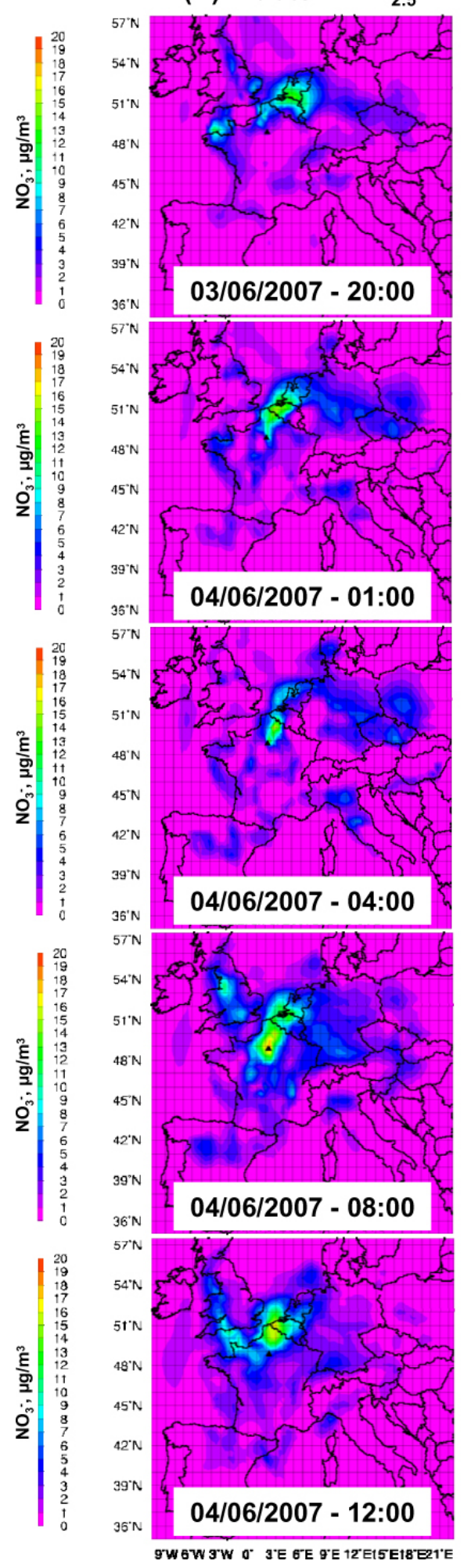

(B) sulfate in $\mathrm{PM}_{2.5}$
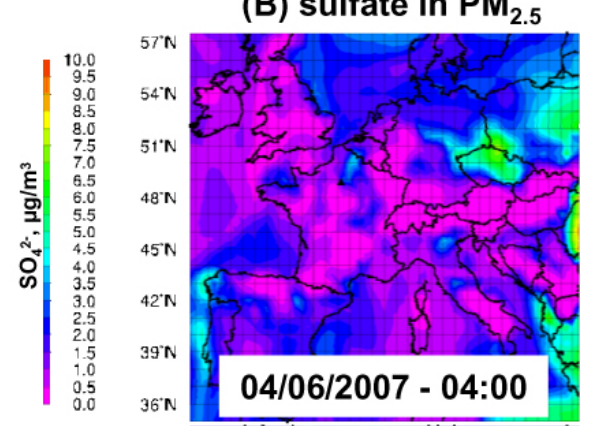

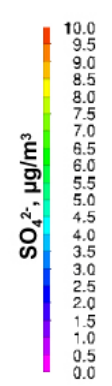

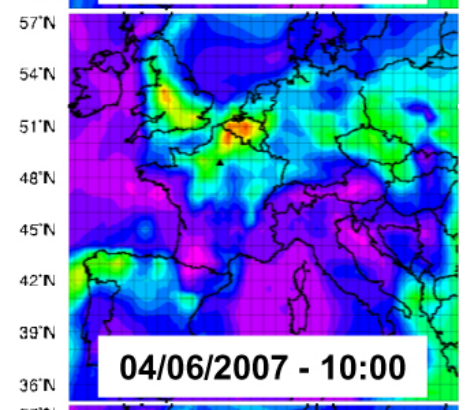

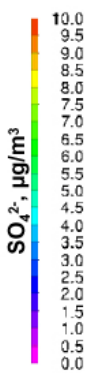

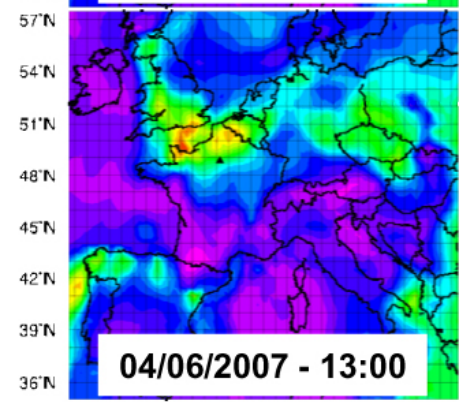

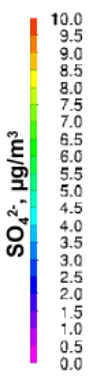

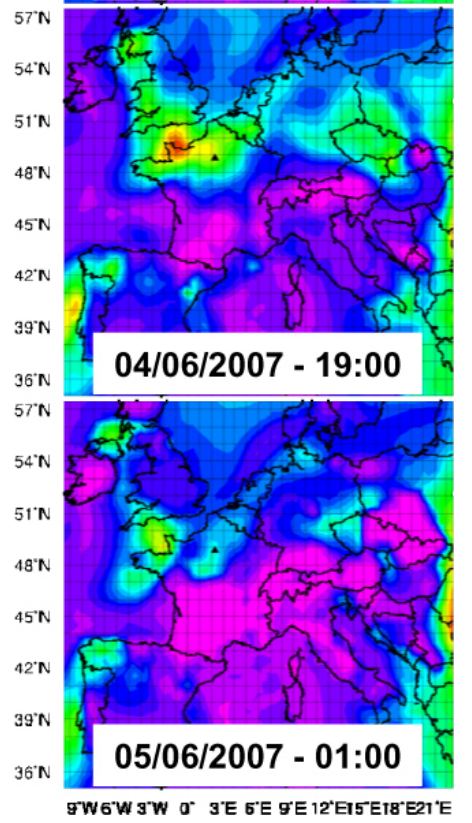

Fig. 8. Plume case study modeled by CHIMERE for fine nitrate (A) and fine sulfate (B) for the period 3-5 June 2007. 


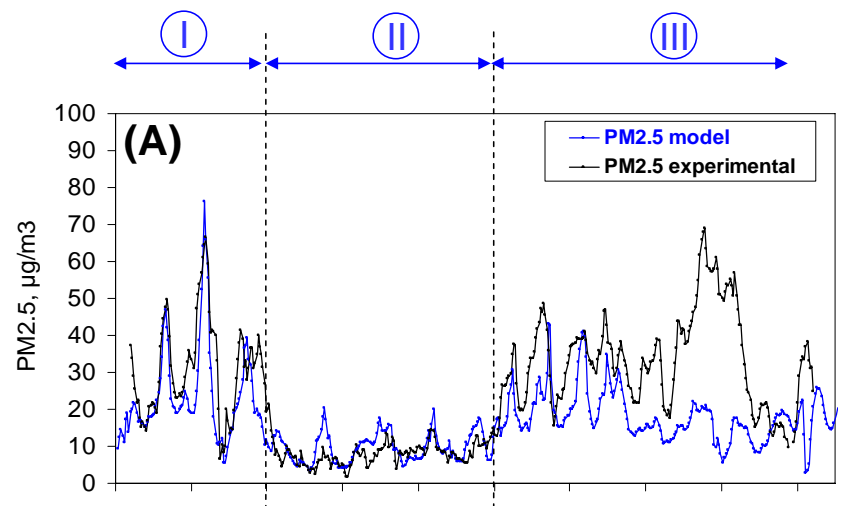

23/05 25/05 27/05 29/05 31/05 02/06 04/06 06/06 08/06 10/06

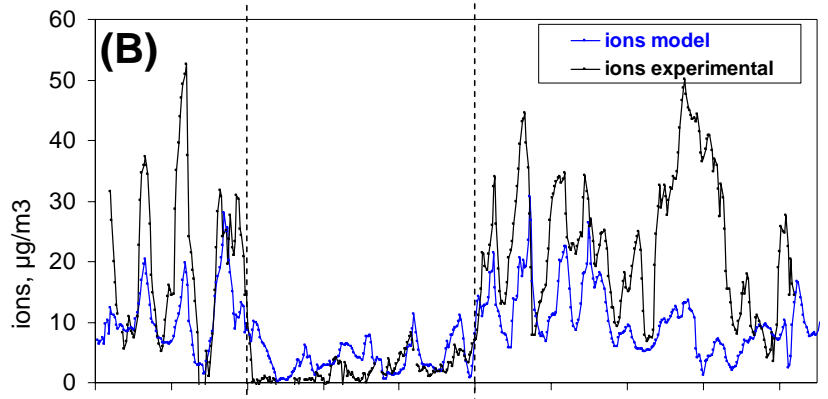

23/05 25/05 27Y05 29/05 31/05 02/06 04/06 06/06 08/06 10/06

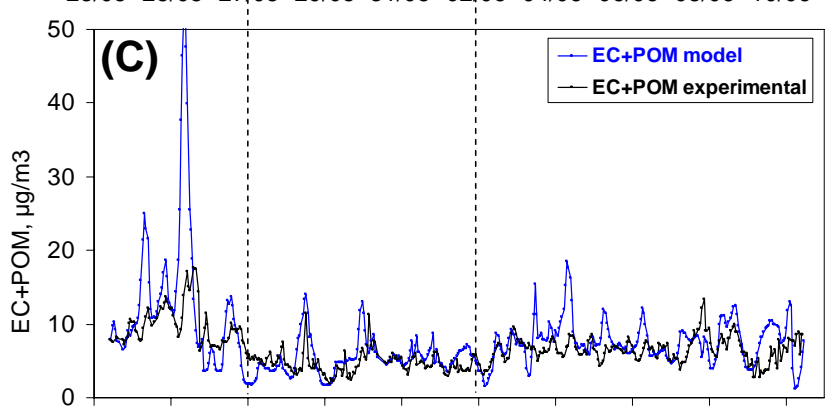

23/05 25/05 27/05 29/05 31/05 02/06 04/06 06/06 08/06 10/06

Fig. 9. Comparison between modeled and measured concentrations of $\mathrm{PM}_{2.5}(\mathbf{A})$, ion species (ammonium nitrate + ammonium sulfate) (B), and carbonaceous matter $(\mathrm{EC}+\mathrm{POM})(\mathbf{C})$. Periods noted I, II, and III correspond to those reported in Sect. 4.1.

time-resolved (hourly) experimental determination of ions and carbonaceous matter.

Measured and modelled $\mathrm{PM}_{2.5}$ have shown to be correlated $\left(r^{2}=0.63 ; N=354\right)$ with a slope of 1.10 (i.e. $\sim 10 \%$ underestimation of model results) and intercept of $3.4 \mu \mathrm{g} \mathrm{m}^{-3}$. First, the general good agreement observed in this Figure for all the chemical constituents of fine aerosols demonstrates the capability of the model to account for most of their variability and concentrations observed in Paris. As previously reported from experimental data (Sect. 4), the model results clearly show that all the temporal variability of $\mathrm{PM}_{2.5}$ is due to a similar one in ions. The poor temporal variability of carbonaceous matter is also properly reproduced by the model.

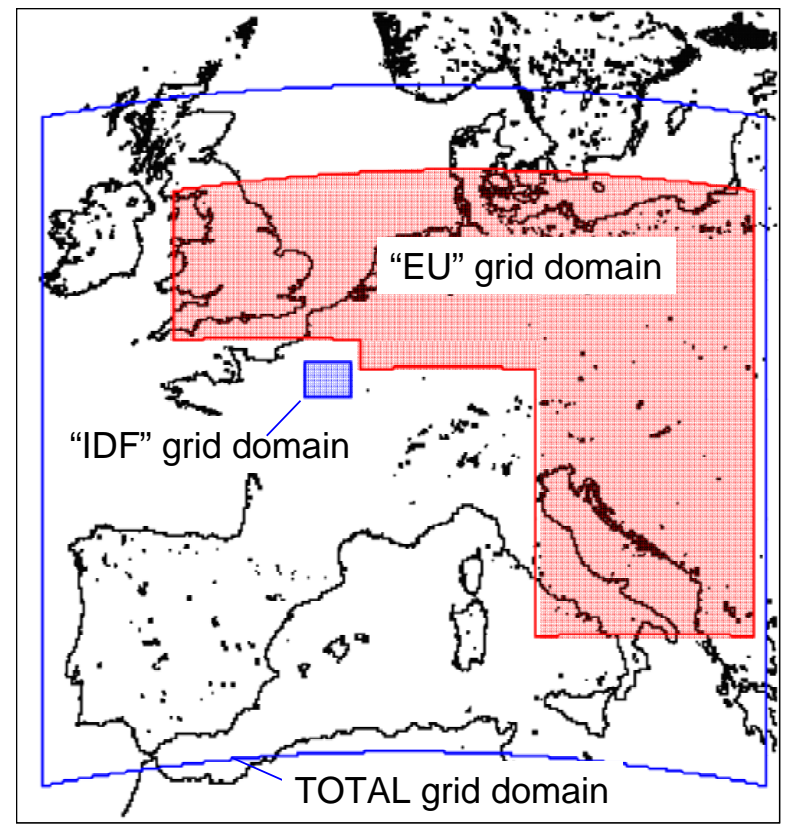

Fig. 10. Grid domain of the chemistry transport model CHIMERE. In blue the "IDF" domain comprises the Ile-de-France region surrounding Paris; in red the "EU" domain comprises part of NorthWestern and Central Europe.

Few discrepancies are observed between experimental and modelled results and concern mainly a simulated - but not observed - peak of carbonaceous aerosols (25 May) and, second, a peak of ions observed for the period (7-9 June) not seen by the model. On 25 May, simulated carbonaceous aerosol is largely overestimated (as well as $\mathrm{NO}_{\mathrm{x}}$ ). This is due to an underestimated boundary layer height, simulated at below $200 \mathrm{~m}$ at 08:00 UTC, as compared to an observed one at about $500 \mathrm{~m}$ (from aerosol backscatter lidar measurements at the SIRTA site $20 \mathrm{~km}$ in SW of Paris centre, http://sirta.ipsl.polytechnique.fr/data-search/2.html). The non-reproduction by the model of a peak of ions observed for the period (7-9 June) may be due to several reasons: a weak model capability to properly reproduce in time and space rain events which has been made evident for this episode by comparing simulated precipitation fields with observed ones (from rain radar). In general, errors in humidity and cloud water content could also affect ion formation. Last, a fraction of ions is simulated to appear in the coarse mode, which is probably due to numerical diffusion either in the coagulation or condensation scheme.

\subsection{Model evaluation of the local-to-continental contribution to $\mathbf{P M}_{2.5}$ levels in Paris}

In order to better distinguish between local and continental pollution origin, two different domains were defined in the CHIMERE grid domain and reported in Fig. 10: the first 

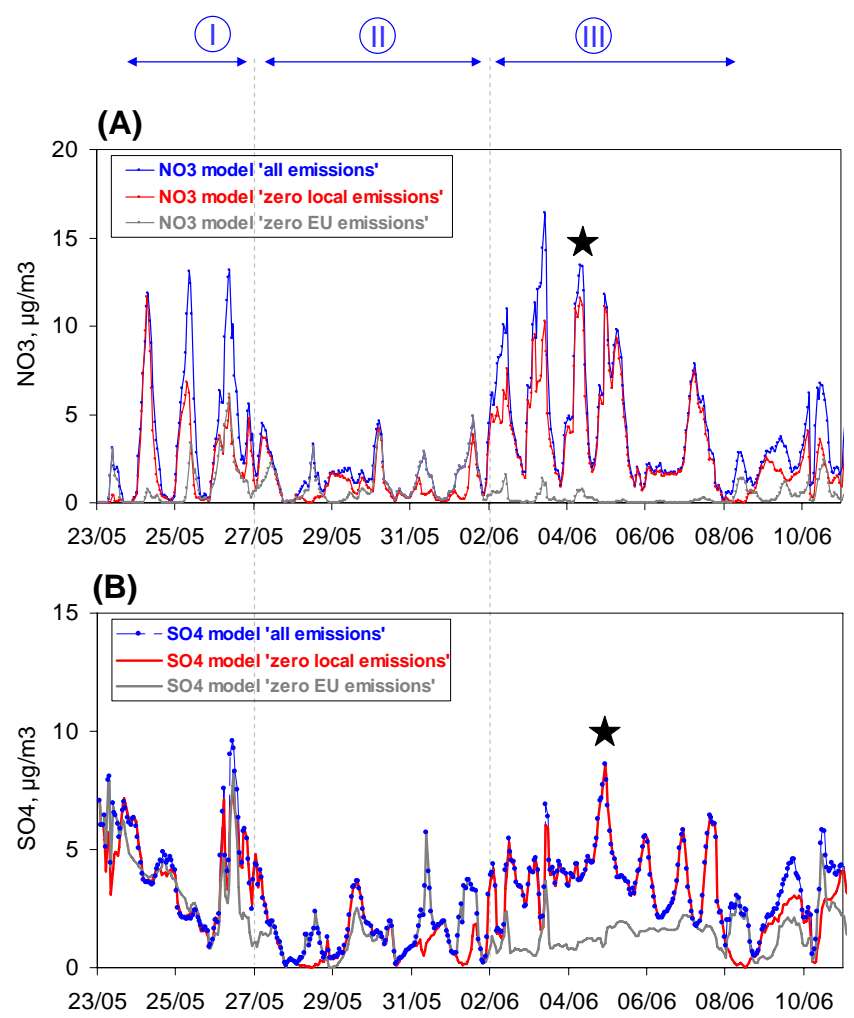

Fig. 11. Model scenarios for fine nitrate (A) and fine sulfate (B) for the reference run ("all emissions" in blue); the scenario with no local (IDF) emissions ("zero local emissions" in red); and the scenario with no European (EU) emissions ("zero EU emissions" in grey). The black star corresponds to the pollution episode (plume case study) depicted in Sect. 5.1.

domain labelled "IDF" (standing for Ile-de-France region) comprises the region of Paris; the second region (labelled "EU") comprises a part of North-Western and Central Europe. Two different scenarios are then evaluated in the following, based on these two grid domains:

- A first scenario labelled "zero local emissions" in which all anthropogenic and biogenic gas and particulate matter emissions from the Ile-de-France region have been removed.

- A second scenario labelled "zero EU emissions" in which all emissions from the EU domain have been removed.

Fine nitrate and fine sulfate simulated with these different scenarios are reported in Fig. 11. The reference run is labelled as "all emissions" in this Figure. Note that the sum of the red (zero local emissions) and grey lines (zero EU emissions) can exceed the blue line (reference) in Fig. 8, due to non-additive effects (thermodynamic equilibrium, impact of emissions on $\mathrm{OH} . .$. ) and emissions for the rest of Europe (out of the two domains defined in Fig. 10).
Model scenarios for nitrate: as shown in Fig. 11a, the nitrate "zero local emissions" curve is often close to the one of the nitrate reference run ("all emissions"). This indicates that local emissions ( $\mathrm{NOx}, \mathrm{NH}_{3}$ ) do not contribute significantly to the observed nitrate concentrations. On few occasions, local emissions can contribute significantly to nitrate as it can be seen for the mornings of 26 May, 27 May, 2 June, 3 June, and 10 June. Nevertheless, most of the sharp maxima observed in nitrate concentrations cannot be explained by local emissions and necessarily involve a significant contribution from abroad. For the second scenario (zero EU emissions), modelled nitrate concentrations modelled are very low which clearly shows that the EU domain defined in Fig. 10 is the major contributor to nitrate concentrations observed in Paris during periods with continental air masses. A raw calculation shows that the EU domain contributes here as much as $75 \%$ of the nitrate concentrations modelled over Paris, local emissions contributing to the remaining $25 \%$.

Model scenarios for sulfate: as shown in Fig. 11b, the sulfate "zero local emissions" curve is almost entirely related to the one of the sulfate reference run ("all emissions"). This clearly indicates that local emissions cannot be considered as a significant source of sulfate in Paris. It is very interesting to note here that the scenario "zero EU emissions" still shows significant modelled sulfate concentrations. This indicates that sulfate concentrations observed in Paris may originate from a larger European domain that the EU domain defined in Fig. 10. A raw calculation shows that the EU domain contributes here to about $40 \%$ of the sulfate concentrations modelled over Paris, local emissions contributing only to $15 \%$.

All these results on nitrate and sulfate unambiguously show the major contribution of emissions from the NorthWestern/Central Europe, especially during the periods with high $\mathrm{PM}_{2.5}$ concentrations, pointing out the need for larger scale abatement strategies to reduce $\mathrm{PM}_{2.5}$ in the Paris region. These results are consistent with literature which has reported a major contribution of regional (trans-boundary) origin for secondary inorganic salts in selected European cities (Querol et al., 2004; Abdalmogith and Harisson, 2005; Salvador et al., 2008).

Model scenarios for carbonaceous species: results for the two scenarios ("zero local emissions" and "zero EU emissions") for primary carbonaceous aerosols clearly point to a major contribution of local sources (data not shown here), which appears to be consistent with our previous observations. Discrimination between primary and secondary organic aerosols is needed here to better characterize local and continental emissions. To do so, a focus is put hereafter on discrimination between primary and secondary organic aerosols (SOA), the latter being defined here as originating from gas-to-particle conversion of VOC. Different experimental methods are used in the following to discriminate between primary and secondary organic aerosols and are then compared with model output in order to depict local and continental contributions. 


\subsection{Experimental evaluation of primary and secondary organic aerosols}

It has been shown previously, that a dominant fraction of carbonaceous aerosols (EC+POM) was of local origin. However, this does not necessarily imply that all these particles are of primary origin. As shown in Fig. 6 the increase of $\mathrm{OC}$ in the afternoon is observed at the maximum of solar radiation and may correspond to a secondary production mechanism of organic aerosol, probably induced by photochemistry. This result is consistent with the photochemical production of organics reported and discussed in details by Favez et al. (2007) for the Paris region during summer. Two different methods are applied hereafter to estimate experimentally the fraction of secondary organic aerosols.

The "WSOC" method: the first one is based on the use of WSOC as a proxy for oxygenated secondary organics. There are many known sources for organic compounds that are soluble in water. These include both primary emissions and secondary products from both biogenic sources and anthropogenic sources (e.g. Forstner et al., 1997; Seinfeld and Pandis, 1998; Kroll et al., 2005). Many of the biomass burning compounds are also watersoluble (Novakov and Corrigan, 1996; Narukawa et al., 1999; Graham et al., 2002; MayolBracero et al., 2002). During our study, the biomass burning contribution to carbonaceous aerosols is considered as negligible. This is supported by co-located VOC measurements showing a very low contribution $(2 \%)$ of the wood burning source (Gaimoz et al., 2010). This is also supported by an averaged angstrom exponent value (deduced from the 7 -wavelenght aethalometer) close to 1.0 , a value which is characteristic for fossil fuel absorbing aerosols (Sandradewi et al., 2008). In the absence of biomass burning, the major WSOC source is thought to be from SOA formation from semi-volatile VOC (Saxena and Hildemann, 1996). A large amount of studies have reported the strong connection between WSOC and secondary organics - possibly of biogenic origin - and have concluded that SOA could be approximated by WSOC (Sullivan et al., 2004; Heald et al., 2006; Myazaki et al., 2006; Kondo et al., 2007; Sullivan et al., 2006; Weber et al., 2007; Hennigan et al., 2008a, b). Based on these studies and the weak contribution of biomass burning aerosols, our WSOC data have been considered as a good surrogate for SOA. Primary organic aerosols (POA) are then assumed to correspond to water insoluble organic matter (WIOM). WSOM and WIOM are calculated here using WSOC and WIOC data from filter sampling. WSOC-to-WSOM and WIOC-to-WIOM conversion factors of 2.1 and 1.3 , respectively, are taken here (Turpin and Lim, 2001; Zhang et al., 2005).

The "EC-tracer" method: this method is often used in literature to derive SOA (e.g. Turpin and Huntzicker, 1991; Turpin and Huntzicker, 1995; Strader et al., 1999; Lim and Turpin, 2002; Cabada et al., 2004). It is based on the use of a minimum in the OC/EC ratio which can be related to primary emissions and which is used to calculate POA; any increase of the OC/EC above this minimum is considered to be related to a secondary production of organic aerosols. One of the critical issues in using this method is the proper choice of OC/EC ratio of primary origin. Our lowest OC/EC ratios $(\sim 0.7)$ were taken as the one characteristic for primary emissions. These ratios were observed at the morning peak of EC (traffic) and for the period II which is characterized by air masses originating from the ocean (i.e. minimizing continental emissions of gas and particulate organic material). These ratios of 0.7 are in good agreement with those reported by Lonati et al. (2007) and El Haddad et al. (2009) for measurements performed in tunnels in Italy and France, respectively. Primary organic carbon (POC) was then calculated using the equation $[\mathrm{POC}] /[\mathrm{EC}]=0.7$. Secondary Organic Carbon (SOC) was then calculated as the difference between OC and POC. SOA and POA from the EC-tracer method were calculated using a SOC to SOA and POC to POA conversion factors of 2.1 and 1.3 , respectively (Turpin and Lim, 2001; Zhang et al., 2005).

Comparison between the two POA datasets and the 2 SOA datasets calculated from the two different approaches ("WSOC" and "EC-tracer" methods) is reported in Fig. 12 and shows comparable (but poorly correlated) mean concentration levels (typically around $1-2 \mu \mathrm{g} \mathrm{m}^{-3}$ for POA, and 3 $5 \mu \mathrm{g} \mathrm{m}^{-3}$ for SOA). The small number of data points available for comparison $(N=18)$ makes difficult to bring further explanation on the discrepancy between the two methods. A first explanation can be related to the validity of the water soluble properties of SOA since freshly formed water insoluble SOA has already been reported in urban atmosphere (Favez et al., 2008). Beyond this discrepancy, it remains interesting to note that SOA determined by the EC-tracer method is clearly influenced by air mass origin, the highest SOA levels being observed for the periods I and III with mean concentrations of $6.7 \pm 2.7 \mu \mathrm{g} \mathrm{m}^{-3}$ and $3.6 \pm 1.5 \mu \mathrm{g} \mathrm{m}^{-3}$, respectively. As for ion species, it is legitimate to assume that European emissions may have contributed to these high levels of SOA through high emissions of biogenic and anthropogenic gas precursors. Significant amounts of SOA $\left(2.7 \pm 1.7 \mu \mathrm{g} \mathrm{m}^{-3}\right)$ are still determined for the second period which is characterized by marine air masses having residence times of less than $10 \mathrm{~h}$ over the continent. Marine SOA are likely to play a very minor role compared to continental sources (O'dowd et al., 2004; Sciare et al., 2009; Arnold et al., 2009; Myriokefalitakis et al., 2010) and cannot considered be here as a significant SOA contributor. Consequently, a non negligible formation of fresh SOA in the region upwind of Paris could be proposed here to explain the levels of SOA for the second period with marine air masses. This is confirmed by the SOA/OA ratio which is not significantly affected by air masses origin, showing average values of $79 \%, 73 \%$, and $72 \%$ for the 3 consecutive periods, respectively. Such results clearly illustrate the strong potential to create rapidly significant amounts of SOA in the French regions upwind of Paris. 


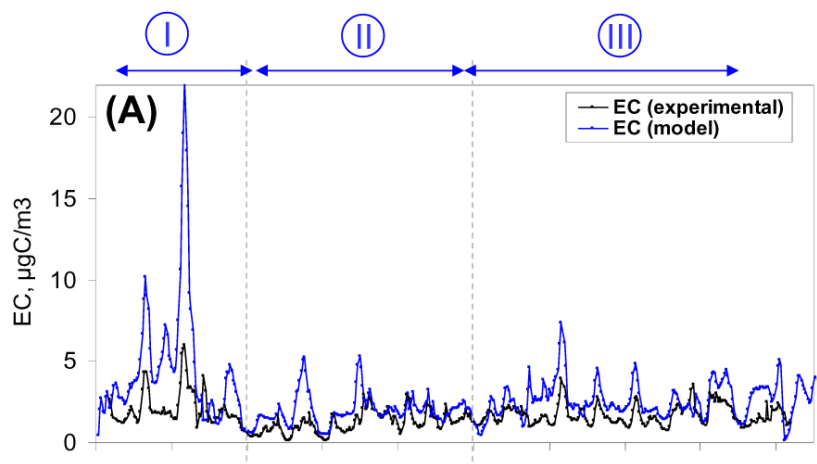

23/05 25/05 27/05 29/05 31/05 02/06 04/06 06/06 08/06 10/06

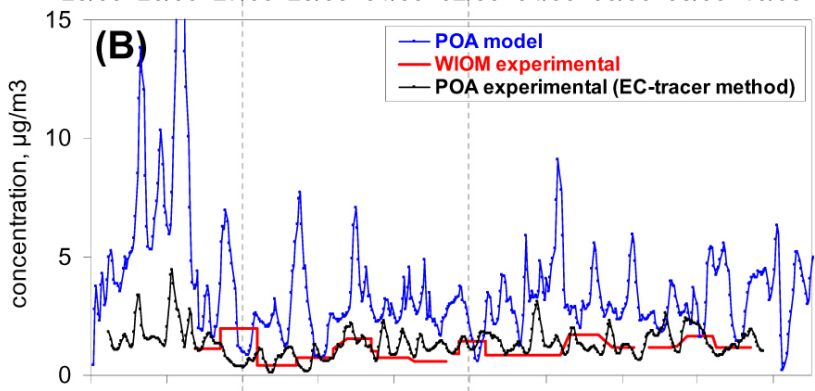

23/05 25/05 27/05 29/05 31/05 02/06 04/06 06/06 08/06 10/06

$$
15
$$

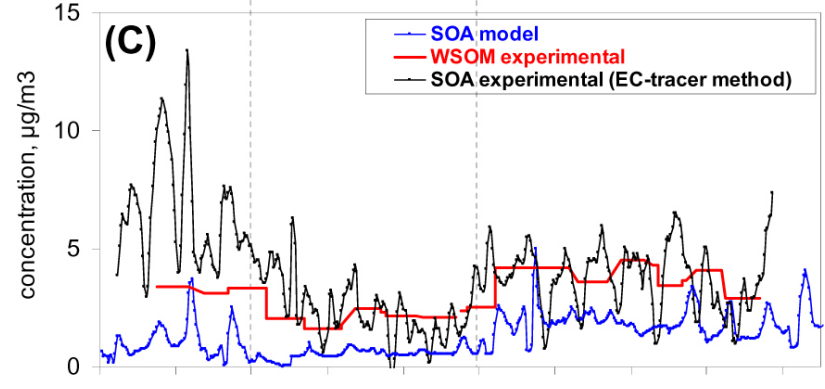

23/05 25/05 27/05 29/05 31/05 02/06 04/06 06/06 08/06 10/06

Fig. 12. Comparison of EC (A), POA (B), and SOA (C) determined from the CHIMERE model (in blue); the "EC-tracer" method (in black); and the "WSOC" method (in red).

\subsection{Comparison between modelled and experimentally determined primary and secondary organic aerosols}

Measured and modeled concentration of carbonaceous aerosols (EC+POM) has shown previously quite similar concentration levels (Fig. 9c). Comparison of the different carbonaceous fractions (EC, POA, SOA) is much less satisfactory (Fig. 12). Although averaged measured and modeled EC concentrations are quite similar, they present a poor correlation coefficient $\left(r^{2}=0.52\right)$. Modeled POA is a factor of two higher than the EC-tracer derived POA. By contrast, model derived SOA is a factor of two lower compared to the one estimated with the EC-tracer method. Consequently, the concordance between modeled and measured concentration of carbonaceous aerosols (EC+POM) observed in Fig. 9c is mainly due to compensating errors resulting in an overestimation (respectively underestimation) of POA (respec- tively SOA). Overestimation of modeled POA may be due to the fact that POA is considered as non-volatile in the model while it has been recognized recently of being volatile (Robinson et al., 2007). Understimation of simulated SOA is not unexpected, because several potentially important SOA sources (evaporation and aging of POA, oligomerisation) are not considered here. In the model, EC and POA are clearly of local origin, which is consistent with the disconnected variations of carbonaceous aerosol and ions observed in experimental data. However, due to the underestimation of SOA, the model cannot be used at this stage to further conclude on the local/continental origin of experimentally derived SOA.

\section{Conclusions}

Time-resolved measurements of the chemical composition of fine aerosols were performed in Paris (France) during springtime and used to calculate hourly concentrations of ions (ammonium nitrate + ammonium sulfate) and carbonaceous aerosols (EC+POM) in $\mathrm{PM}_{2.5}$. These two components have been shown to be the main contributors to $\mathrm{PM}_{2.5}$ in Paris, although their fraction appeared to be highly variable, ranging from 25 to $75 \%$.

Periods with high levels of $\mathrm{PM}_{2.5}\left(>10-15 \mu \mathrm{g} \mathrm{m}^{-3}\right)$ were shown to be associated with continental air masses regimes and were mainly composed of ions. During these periods, diurnal variations of ions in Paris were dependent on local thermodynamic conditions responsible for the condensation/evaporation of semi-volatile ammonium nitrate. The comparison of our $\mathrm{PM}_{2.5}$ dataset with others obtained in the North of France during the same period has shown that these intense pollution episodes were not a local pattern of the region of Paris but corresponded to spatially extended phenomena originating from continental Europe. Comparison with VOC measurements performed in parallel has revealed a close relationship between ions and oxygenated VOCs (methanol, acetone) with higher concentrations during periods influenced by continental air masses. Both fractions being produced through photochemical processes, their apparent concordance suggested that Paris region was under the influence of continental photochemically aged air masses during the episodes with elevated $\mathrm{PM}_{2.5}$ levels. In contrast with ion species, concentrations of carbonaceous aerosols observed during this study were less variable (weakly influenced by air masses origin), suggesting a more local pattern, at least for the primary fraction of this fraction.

In order to determine local and continental contributions to the concentration levels and composition of fine aerosols over the Paris region, chemistry transport model simulations were performed with the CHIMERE model. The comparison appeared to be satisfactory, the model being able to predict most of the occurrences of observed $\mathrm{PM}_{2.5}$ and ion species peaks. Specifically, the model is shown to overestimate the local influence (primary carbonaceous aerosol) while underestimating SOA and continental advection of ions to the area. 
Different scenarios were evaluated with this model, switching OFF local and continental emissions, respectively. Results obtained for ions clearly showed a major influence of continental emissions (North-Western and Central Europe), with a contribution of about $75 \%$ and $40 \%$ for nitrate and sulfate, respectively. Although these results clearly need to be extended for larger time periods, they suggest that EU emissions may play a significant role during periods with high $\mathrm{PM}_{2.5}$ levels over the Paris region. This result is relevant for local policy makers who have to propose efficient abatement strategies aiming at reducing $\mathrm{PM}_{2.5}$ concentration levels in the context of an EU limit value of $25 \mu \mathrm{g} \mathrm{m}^{-3}$ in 2015 (20 $\mu \mathrm{m} \mathrm{m}^{-3}$ in 2020). On the other hand, implications of our results for health issues are less evident since the $\mathrm{PM}_{2.5}$ peak values of fine aerosols observed during our study were mainly composed of ions, which present a poor toxicity in comparison to other trace elements in fine aerosols (metals, PAH, ...).

Finally, the local/continental contribution to secondary organic aerosols measured over Paris has been investigated. Two different methods were used to experimentally estimate the secondary fraction of organic aerosols and showed that SOA were likely to play a major role in Paris during springtime, representing about $75 \%$ of the total mass concentration of organic aerosols. As expected, periods influenced by photochemically processed continental air masses showed the highest concentrations of SOA. Surprisingly, our results suggest that the abundance of SOA (relatively to OA) did not exhibit significant changes between the periods influenced by clean marine and photochemically processed continental air masses, respectively. Although this work has provided limited information on (S)OA, these results suggest that regional emissions may have been quite important and/or have reacted quite rapidly, bringing the relative abundance of SOA at similar levels compared to continental aged air masses. Comparison between modeled and measured primary (respectively secondary) organic aerosols has shown significant discrepancies with overestimation (respectively underestimation) by a factor of 2 for model calculation, pointing out the need for a better model evaluation of processes leading to SOA.

Acknowledgements. This work was supported by the Agence Nationale de la Recherche (ANR) through the AEROCOV project, ADEME, CNRS, and CEA. Authors want to acknowledge LHVP (A. Person, Y. Le Moullec) for having hosted this field experiment. Contribution of local air quality networks (AIRPARIF, LIGAIR, ATMO NORD PAS-DE-CALAIS, AIR NORMAND, ATMO CHAMPAGNE-ARDENNE, and ATMO PICARDIE) are also acknowledged here through the access of $\mathrm{PM}_{2.5}$ data at Paris, Bethune, and St Jean and emission data. Modeling results have been obtained under Ph-D grant funding by CIFRE (ANRT) attributed to ARIA Technologies and LISA. The authors gratefully acknowledge the NOAA Air Resources Laboratory (ARL) for the provision of the HYSPLIT transport and dispersion model and/or READY website (http://www.arl.noaa.gov/ready.php) used in this publication.
Edited by: M. Kanakidou

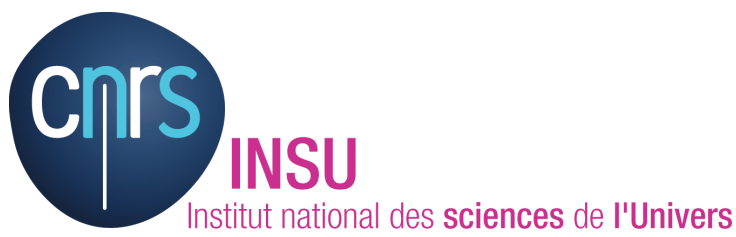

The publication of this article is financed by CNRS-INSU.

\section{References}

Abdalmogith, S. S. and Harrison, R. M.: The use of trajectory cluster analysis to examine the long-range transport of secondary inorganic aerosol in the UK, Atmos. Environ., 39, 6686-6695, 2005.

Ansari, A. S. and Pandis, S. N.: An analysis of four models predicting the partitioning of semi-volatile inorganic aerosol components, Aerosol Sci. Tech., 31, 129-153, 1999.

Arhami, M., Kuhn, T., Fine, P. M., Delfino, R. J., and Sioutas, C.: Effects of sampling artifacts and operating parameters on the performance of a semicontinuous particulate elemental carbon/organic carbon monitor, Environ. Sci. Technol., 40, 945954, 2006.

Arnold, S. R., Spracklen, D. V., Williams, J., Yassaa, N., Sciare, J., Bonsang, B., Gros, V., Peeken, I., Lewis, A. C., Alvain, S., and Moulin, C.: Evaluation of the global oceanic isoprene source and its impacts on marine organic carbon aerosol, Atmos. Chem. Phys., 9, 1253-1262, doi:10.5194/acp-9-1253-2009, 2009.

Bae, M. S., Schauer, J. J., DeMinter, J. T., Turner, J. R., Smith, D., and Cary, R. A.: Validation of a semi-continuous instrument for elemental carbon and organic carbon using a thermal-optical method, Atmos. Environ., 38, 2885-2893, 2004.

Beekmann, M. and Derognat, C.: Monte Carlo uncertainty analysis of a regional scale transport chemistry model constrained by Measurements from the Esquif campaign, J. Geophys. Res., 108, 8559, doi:10.1029/2003JD003391, 2003.

Bessagnet, B., Hodzic, A., Vautard, R., Beekmann, M., Cheinet, S., Honoré, C., Liousse, C., and Rouil, L.: Aerosol modelling with Chimere - Preliminary evaluation at the continental scale, Atmos. Environ., 38, 2803-2817, 2004.

Bessagnet, B., Hodzic, A., Blanchard, O., Lattuati, M., Le Bihan, O., Marfaing, H., and Rouil, L.: Origin of particulate matter pollution episodes in wintertime over the Paris basin, Atmos. Environ., 39, 6159-6174, 2005.

Bessagnet, B., Menut, L., Curci, G., Hodzic, A., Guillaume, B., Liousse, C., Moukhtar, S., Pun, B., Seigneur, C., and Schulz, M.: Regional modeling of carbonaceous aerosols over Europe focus on secondary organic aerosols, J. Atmos. Chem., 61, 175202, 2008.

Birch, M. E. and Cary, R. A., Elemental carbon-based method for monitoring occupational exposures to particulate diesel exhaust, Aerosol Sci. Tech., 25, 221-241, 1996.

Cabada, J. C., Pandis, S. N., Subramanian, R., Robinson, A. L., Polidori, A., and Turpin, B.: Estimating the Secondary Organic Aerosol Contribution to $\mathrm{PM}_{2.5}$ Using the EC Tracer Method, Aerosol Sci. Technol., 38(12), 140-155, 2004. 
Charron, A., Harrison, R. M., Moorcroft, S., and Booker, J.: Quantitative interpretation of divergence between $\mathrm{PM}_{10}$ and $\mathrm{PM}_{2.5}$ mass measurement by TEOM and gravimetric (Partisol) instruments, Atmos. Environ., 38, 415-423, 2004.

Curci, G., Beekmann, M., Vautard, R., Smiatek, G., Steinbrecher, R., Theloke, J., and Friedrich, R.: Modelling study of the impact of isoprene and terpene biogenic emissions on European ozone levels, Atmos. Environ., 43, 1444-1455, 2009.

Derognat, D., Beekmann, M., Baeumle, M., Martin, D., and Schmidt, H.: Effect of biogenic VOC emissions on the tropospheric chemistry during elevated ozone periods in Ile de France, J. Geophys. Res., 108, 8560, doi:10.1029/2001JD001421, 2003.

Deguillaume, L., Beekmann, M., and Menut, L.: Bayesian Monte Carlo analysis applied to regional scale inverse emission modelling for reactive trace gases, J. Geophys. Res., 112, D02307, doi:10.1029/2006JD007518, 2007.

Deguillaume, L., Beekmann, M., and Derognat, C.: Uncertainty evaluation of ozone production and its sensitivity to emission changes over the Ile-de-France region during summer periods, J. Geophys. Res., 113, D02304, doi:10.1029/2007JD009081, 2008.

Draxler, R. R. and Rolph, G. D.: HYSPLIT (HYbrid Single-Particle Lagrangian Integrated Trajectory) Model access via NOAA ARL READY Website (http://www.arl.noaa.gov/ HYSPLIT.php), NOAA Air Resources Laboratory, Silver Spring, MD, 2003.

Dudhia, J.: A nonhydrostatic version of the Penn State/NCAR mesoscale model: validation tests and simulation of an Atlantic cyclone and cold front, Mon. Weather Rev., 121, 1493-1513, 1993.

El Haddad, I., Marchand, N., Dron, J., Temime-Roussel, B., Quivet, E., Wortham, H., Jaffrezo, J. L., Baduel, C., Voisin, D., Besombes, J. L., and Gille, G.: Comprehensive primary particulate organic characterization of vehicular exhaust emissions in France, Atmos. Environ., 43(39), 6190-6198, 2009.

Fan, X., Lee, P. K. H., Brook, J. R., and Mabury, S. A.: Improved measurement of seasonal and diurnal differences in the carbonaceous components of urban particulate matter using a denuderbased air sampler, Aerosol Sci. Technol., 38, 63-69, 2004.

Favez, O., Cachier, H., Sciare, J., and Le Moullec, Y.: Characterization and contribution to $\mathrm{PM}_{2.5}$ of semi-volatile aerosols in Paris (France), Atmos. Environ., 41, 7969-7976, 2007.

Favez, O., Sciare, J., Cachier, H., Alfaro, S. C., and Abdelwahab, M. M.: Significant formation of water-insoluble secondary organic aerosols in semi-arid urban environment, Geophys. Res. Lett., 35, L15801, doi:10.1029/2008GL034446, 2008.

Forstner, H. J. L., Seinfeld, J. H., and Flagan, R. C.: Secondary organic aerosol from the photooxidation of aromatic hydrocarbons: Molecular composition, Environ. Sci. Technol., 31, 1345-1358, 1997.

Friedrich, R.: GENEMIS: assessment, improvement, temporal and spatial disaggregation of European emission data, in: Tropospheric Modelling and Emission Estimation, Part 2., edited by: Ebel, A., Friedrich, R., and Rhode, H., Springer, New York, 181214, 1997.

Gaimoz, C., Sauvage, S., Gros, V., Herrmann, F., Williams, J., Locoge, N., Perrussel, O., Bonsang, B., d'Argouges, O., SardaEstève, R., and Sciare, J.: Volatile organic compounds sources in Paris in spring 2007. Part II: source apportionment using positive matrix factorization, Environ. Chem., in press, 2010.
Graham, B., Mayol-Bracero, O. L., Guyon, P., Roberts, G. C., Decesari, S., Facchini, M. C., Artaxo, P., Maenhaut, W., Köll, P., and Andreae, M. O.: Water-soluble organic compounds in biomass burning aerosols over Amazonia: 1. Characterization by NMR and GC-MS, J. Geophys. Res., 107(D20), 8047, doi:10.1029/2001JD000336, 2002.

Gros, V., Sciare, J., and Yu, T.: Air Quality Air-quality measurements in megacities: Focus on gaseous organic and particulate pollutants and comparison between two contrasted cities, Paris and Beijing, C. R. Geosci., 339, 764-774, 2007.

Gros, V., Gaimoz, C., Herrmann, F., Custer, T., Williams, J., Bonsang, B., Sauvage, S., Locoge, N., d'Argouges, O., Sarda-Estève, R., and Sciare, J.: Volatile organic compounds sources in Paris in spring 2007. Part I: qualitative analysis, Environ. Chem., in press, 2010.

Grover, B. D., Kleinman, M., Eatough, N. L., Eatough, D. J., Hopke, P. K., Long, R. W., Wilson, W. E., Meyer, M. B., and Ambs, J. L.: Measurement of total $\mathrm{PM}_{2.5}$ mass (nonvolatile plus semivolatile) with the Filter Dynamic Measurement System tapered element oscillating microbalance monitor, J. Geophys. Res., 110, D07S03, doi:10.1029/2004JD004995, 2005.

Guenther, A., Karl, T., Harley, P., Wiedinmyer, C., Palmer, P. I., and Geron, C.: Estimates of global terrestrial isoprene emissions using MEGAN (Model of Emissions of Gases and Aerosols from Nature), Atmos. Chem. Phys., 6, 3181-3210, doi:10.5194/acp-63181-2006, 2006.

Guinot, B., Cachier, H., and Oikonomou, K.: Geochemical perspectives from a new aerosol chemical mass closure, Atmos. Chem. Phys., 7, 1657-1670, doi:10.5194/acp-7-1657-2007, 2007.

Gurjar, B. R., Butler, T. M., Lawrence, M. G., and Lelieveld, J.: Evaluation of emissions and air quality in megacities, Atmos. Environ., 42, 1593-1606, 2008.

Hauglustaine, D. A., Hourdin, F., Jourdain, L., Filiberti, M.-A., Walters, S., Lamarque, J.-F., and Holland, E. A.: Interactive chemistry in the Laboratoire de Météorologie Dynamique general circulation model: Description and background tropospheric chemistry evaluation, J. Geophys. Res., 109, D04314, doi:10.1029/2003JD003957, 2004.

Heald, C. L., Jacob, D. J., Turquety, S., Hudman, R. C., Weber, R. J., Sullivan, A. P., Peltier, R. E., Atlas, E. L., de Gouw, J. A., Warneke, C., Holloway, J. S., Neuman, J. A., Flocke, F. M., and Seinfeld, J. H.: Concentrations and sources of organic carbon aerosols in the free troposphere over North America, J. Geophys. Res., 111, D23S47, doi:10.1029/2006JD007705, 2006.

Hennigan, C. J., Bergin, M. H., Dibb, J. E., and Weber, R. J.: Enhanced secondary organic aerosol formation due to water uptake by fine particles, Geophys. Res. Lett., 35, L18801, doi:10.1029/2008GL035046, 2008a.

Hennigan, C. J., Sullivan, A. P., Fountoukis, C. I., Nenes, A., Hecobian, A., Vargas, O., Peltier, R. E., Case Hanks, A. T., Huey, L. G., Lefer, B. L., Russell, A. G., and Weber, R. J.: On the volatility and production mechanisms of newly formed nitrate and water soluble organic aerosol in Mexico City, Atmos. Chem. Phys., 8, 3761-3768, doi:10.5194/acp-8-3761-2008, 2008 b.

Hodzic, A., Vautard, R., Chazette, P., Menut, L., and Bessagnet, B.: Aerosol chemical and optical properties over the Paris area within ESQUIF project, Atmos. Chem. Phys., 6, 3257-3280, doi:10.5194/acp-6-3257-2006, 2006.

Honoré, C. , Rouïl, L., Vautard, R., Beekmann, M., Bessagnet, 
B., Dufour, A., Elichegaray, C., Flaud, J.-M., Malherbe, L., Meleux, F., Menut, L., Martin, D., Peuch, A., Peuch, V. H., and Poisson, N.: Predictability of European air quality: The assessment of three years of operational forecasts and analyses by the PREV'AIR system, J. Geophys. Res., 113, D04301, doi:10.1029/2007JD008761, 2008.

Junker, C. and Liousse, C.: A global emission inventory of carbonaceous aerosol from historic records of fossil fuel and biofuel consumption for the period 1860-1997, Atmos. Chem. Phys., 8, 1195-1207, doi:10.5194/acp-8-1195-2008, 2008.

Kondo, Y., Miyazaki, Y., Takegawa, N., Miyakawa, T., Weber, R. J., Jimenez, J. L., Zhang, Q., and Worsnop, D. R.: Oxygenated and water-soluble organic aerosols in Tokyo, J. Geophys. Res., 112, D01203, doi:10.1029/2006JD007056, 2007.

Konovalov, I. B., Beekmann, M., Richter, A., and Burrows, J. P.: Inverse modelling of the spatial distribution of $\mathrm{NO}_{\mathrm{x}}$ emissions on a continental scale using satellite data, Atmos. Chem. Phys., 6, 1747-1770, doi:10.5194/acp-6-1747-2006, 2006.

Kroll, J. H., Ng, N. L., Murphy, S. M., Flagan, R. C., and Seinfeld, J. H.: Secondary organic aerosol formation from isoprene photooxidation under high- $\mathrm{NO}_{\mathrm{x}}$ conditions, Geophys. Res. Lett., 32, L18808, doi:10.1029/2005GL023637, 2005.

Lattuati, M.: Contribution à l'étude du bilan de l'ozone troposphérique à l'interface de l'Europe et de l'Atlantique Nord: Modélisation lagrangienne et mesures en altitude, $\mathrm{Ph} . \mathrm{D}$. thesis, Univ. Pierre et Marie Curie, Paris, France, 1997.

Lim, H.-J. and Turpin, B. J.: Origins of Primary and Secondary Organic Aerosol in Atlanta: Results of Time-Resolved Measurements during the Atlanta Supersite Experiment, Environ. Sci. Technol., 36, 4489-4496, 2002.

Lonati, G., Ozgen, S., and Giugliano, M.: Primary and secondary carbonaceous species in $\mathrm{PM}_{2.5}$ samples in Milan (Italy), Atmos. Environ., 41, 4599-4610, 2007.

Madronich, S., McKenzie, R. E., Bjorn, L. O., and Caldwell, M. M.: Changes in biologically active ultraviolet radiation reaching the earth's surface, J. Photoch. Photobio. B, 46, 5-19, 1998.

Malm, W. C., Sisler, J. F., Huffman, D., Eldred, R. A., and Cahill, T. A.: Spatial and seasonal trends in particle concentration and optical extinction in the United States, J. Geophys. Res., 99, 13471370, 1994

Malm, W. C., Day, D. E., and Kreidenweis, S. M.: Light scattering characteristics of aerosols as a function of relative humidity: part I - a comparison of measured scattering and aerosol concentrations using the theoretical models, J. Air Waste Manage., 50, 686-700, 2000

Mayol-Bracero, O. L., Guyon, P., Graham, B., Roberts, G., Andreae, M. O., Decesari, S., Facchini, M. C., Fuzzi, S., and Artaxo, P.: Water-soluble organic compounds in biomass burning aerosols over Amazonia: 2. Apportionment of the chemical composition and importance of the polyacidic fraction, J. Geophys. Res., 107(D20), 8091, doi:10.1029/2001JD000522, 2002.

Miyazaki, Y., Kondo, Y., Takegawa, N., Komazaki, Y., Fukuda, M., Kawamura, K., Mochida, M., Okuzawa, K., and Weber, R. J.: Time-resolved measurements of water-soluble organic carbon in Tokyo, J. Geophys. Res., 111, D23206, doi:10.1029/2006JD007125, 2006.

Myriokefalitakis, S., Vignati, E., Tsigaridis, K., Papadimas, C., Sciare, J., Mihalopoulos, N., Facchini, M. C., Rinaldi, M., Dentener, F. J., Ceburnis, D., Hatzianastasiou, N., O’Dowd, C. D., van Weele, M., Kanakidou, M.: Global modelling of the oceanic source of organic aerosols, Adv. Meteorol., in press, 2010.

Narukawa, M., Kawamura, K., Takeuchi, N., and Nakajima, T.: Distribution of dicarboxylic acids and carbon isotope compositions in aerosols from 1997 Indonesian forest fires, Geophys. Res. Lett., 26, 3101-3104, 1999.

Nel, A.: Air pollution-related illness: Effects of particles, Science, 308, 804-806, 2005.

Nenes, A., Pilinis, C., and Pandis, S.: ISORROPIA: A new thermodynamic model for inorganic multicomponent atmospheric aerosols, Aquat. Geochem., 4, 123-152, 1998.

Novakov, T. and Corrigan, C. E.: Cloud condensation nucleus activity of the organic component of biomass smoke particles, Geophys. Res. Lett., 16, 2141-2144, 1996.

O’Dowd, C. O., Facchini, M. C., Cavalli, F., Ceburnis, D., Mircea, M., Decesari, S., Fuzzi, S., Yoon, Y. J., and Putaud, J.-P.: Biogenically driven organic contribution to marine aerosol, Nature, 431, 676-680, 2004.

Offenberg, J. H. ,Lewandowski, M., Edney, E. O., Kleindienst, T. E., and Jaoui, M.: Investigation of a Systematic Offset in the Measurement of Organic Carbon with a Semicontinuous Analyzer, J. Air Waste Manage., 57(5), 596-599, 2007.

Ohta, S. and Okita, T.: A chemical characterization of atmospheric aerosol in Sapporo, Atmos. Environ., 24(4), 815-822, 1990.

Patashnik, H. and Rupprecht, E. G.: Continuous PM $_{10}$ measurements using a tapered element oscillating microbalance, J. Air Waste Manage., 41, 1079-1083, 1991.

Peltier, R. E., Weber, R. J., and Sullivan, A. P.: Investigating a liquid-based method for online organic carbon dectection in atmospheric particles, Aerosol. Sci. Technol., 41, 1117-1127, 2007.

Polidori, A., Turpin, B. J., Lim, H.-J., Cabada, J. C., Subramanian, R., Pandis, S. N., and Robinson, A. L.: Local and regional secondary organic aerosol: insights from a year of semi-continuous carbon measurements at Pittsburgh, Aerosol. Sci. Technol., 40, 861-872, 2006.

Pun, B., Seigneur, C., and Lohman, K.: Modeling secondary organic aerosol via multiphase partitioning with molecular data Environ. Sci. Technol., 40, 4722-4731, 2006.

Querol, X., Alastuey, A., Ruiz, C. R., Artinano, B., Hansson, H. C., Harrison, R. M., Buringh, E., ten Brink, H. M., Lutz, M., Bruckmann, P., Straehl, P., and Schneider, J.: Speciation and origin of $\mathrm{PM}_{10}$ and $\mathrm{PM}_{2.5}$ in selected European cities, Atmos. Environ., 38, 6547-6555, 2004.

Ramanathan, V., Li, F., Ramana, M. V., Praveen, P. S., Kim, D., Corrigan, C. E., Nguyen, H., Stone, E. A., Schauer, J. J., Carmichael, G. R., Adhikary, B., and Yoon, S. C.: Atmospheric brown clouds: Hemispherical and regional variations in longrange transport, absorption, and radiative forcing, J. Geophys. Res., 112, D22S21, doi:10.1029/2006JD008124, 2007.

Robinson, A. L., Donahue, N. M., Shrivastava, M. K., Weitkamp, E. A., Sage, A. M., Grieshop, A. P., Lane, T. E., Pierce, J. R., and Pandis, S. N.: Rethinking organic aerosols: Semivolatile emissions and photochemical aging, Science, 315(5816), 1259-1262, 2007.

Rolph, G. D.: Real-time Environmental Applications and Display sYstem (READY) Website (http://www.arl.noaa.gov/ready.php), NOAA Air Resources Laboratory, Silver Spring, MD, 2003.

Ruellan, S. and Cachier, H.: Characterisation of fresh particulate 
vehicular exhausts near a Paris high flow road, Atmos. Environ., 35, 453-468, 2001.

Salvador, P., Artíñanoa, B., Querol, X., and Alastuey, A.: A combined analysis of backward trajectories and aerosol chemistry to characterise long-range transport episodes of particulate matter: The Madrid air basin, a case study, Sci. Total Environ., 390, 495506, 2008.

Sandradewi, J., Prévôt, A. S. H., Szidat, S., Perron, N., Alfarra, M. R., Lanz, V. A., Weingartner, E., and Baltensperger, U.: Using aerosol light absorption measurements for the quantitative determination of wood burning and traffic emission contributions to particulate matter, Environ. Sci. Technol., 42, 3316-3323, 2008.

Saxena, P. and Hildemann, L. M.: Water-soluble organics in atmospheric particles: A critical review of the literature and application of thermodynamics to identify candidate compounds, J. Atmos. Chem., 24, 57-109, 1996.

Schmidt, H., Derognat, C., Vautard, R., and Beekmann, M.: A comparison of simulated and observed ozone mixing ratios for summer of 1998 in Western Europe, Atmos. Environ., 35, 62776297, 2001.

Sciare, J., Oikonomou, K., Cachier, H., Mihalopoulos, N., Andreae, M. O., Maenhaut, W., and Sarda-Estève, R.: Aerosol mass closure and reconstruction of the light scattering coefficient over the Eastern Mediterranean Sea during the MINOS campaign, Atmos. Chem. Phys., 5, 2253-2265, doi:10.5194/acp-5-2253-2005, 2005.

Sciare, J., Cachier, H., Sarda-Estève, R., Yu, T., and Wang, X.: Semi-volatile aerosols in Beijing (R.P. China): Characterization and influence on various $\mathrm{PM}_{2.5}$ measurements, J. Geophys. Res., 112, D18202, doi:10.1029/2006JD007448, 2007.

Sciare, J., Oikonomou, K., Favez, O., Liakakou, E., Markaki, Z., Cachier, H., and Mihalopoulos, N.: Long-term measurements of carbonaceous aerosols in the Eastern Mediterranean: evidence of long-range transport of biomass burning, Atmos. Chem. Phys., 8, 5551-5563, doi:10.5194/acp-8-5551-2008, 2008a.

Sciare, J., Sarda-Estève, R., Favez, O., Cachier, H., Aymoz, G., and Laj, P.: Nighttime residential wood burning evidenced from an indirect method for calculating real-time concentration of particulate organic matter (POM), Atmos. Environ., 42, 2158-2172, 2008 b.

Sciare, J., Favez, O., Oikonomou, K., Sarda-Estève, R., Cachier, H., and Kazan, V.: Long-term observation of carbonaceous aerosols in the Austral Ocean: Evidence of a marine biogenic origin, J. Geophys. Res., 114, D15302, doi:10.1029/2009JD011998, 2009.

Seinfeld, J. H. and Pandis, S. N.: Atmospheric Chemistry and Physics: From Air Pollution to Climate Changes, John Wiley, Hoboken, N. J., 1998.

Strader, R., Lurmann, F., and Pandis, S. N.: Evaluation of Secondary Organic Aerosol Formation in Winter, Atmos. Environ., 33, 4849-4863, 1999.

Sullivan, A. P., Weber, R. J., Clements, A. L., Turner, J. R., Bae, M. S., and Schauer, J. J.: A method for on-line measurement of watersoluble organic carbon in ambient aerosol particles: Results from an urban site, Geophys. Res. Lett., 31, L13105, doi:10.1029/2004GL019681, 2004.
Sullivan, A. P., Peltier, R. E., Brock, C. A., de Gouw, J. A., Holloway, J. S., Warneke, C., Wollny, A. G., and Weber, R. J.: Airborne measurements of carbonaceous aerosol soluble in water over northeastern United States: Method development and an investigation into water-soluble organic carbon sources, J. Geophys. Res., 111, D23S46, doi:10.1029/2006JD007072, 2006.

Tsyro, S.: First estimates of the effect of aerosol dynamics in the calculation of $\mathrm{PM}_{10}$ and $\mathrm{PM}_{2.5}$, EMEP Report (www.emep.int), 2002.

Turpin, B. J. and Huntzicker, J. J.: Secondary formation of organic aerosol in the Los Angeles basin: a descriptive analysis of organic and elemental carbon concentrations, Atmos. Environ., 25, 207-215, 1991.

Turpin, B. J. and Huntzicker, J. J.: Identification of secondary organic aerosol episodes and quantification of primary and secondary organic aerosol concentrations during SCAQS, Atmos. Environ., 29, 3527-3544, 1995.

Turpin, B. J. and Lim, H. J.: Species contributions to $\mathrm{PM}_{2.5}$ mass concentrations: Revisiting common assumptions for estimating organic mass, Aerosol. Sci. Technol., 35, 602-610, 2001.

Valari, M. and Menut, L.: Does increase in air quality models resolution bring surface ozone concentrations closer to reality?, J. Atmos. Ocean. Tech., 25, 1955-1968, 2008.

Vautard, R., Beekmann, M., Roux, J., and Gombert, D.: Validation of a hybrid forecasting system for the ozone concentrations over the Paris region, Atmos. Environ., 35, 2449-2461, 2001.

Verwer, J. G.: Gauss-Seidel Iteration for Stiff ODES from Chemical Kinetics, J. Sci. Comput., 15, 1243-1250, 1994.

Weber, R. J., Sullivan, A. P., Peltier, R. E., Russell, A., Yan, B., Zheng, M., de Gouw, J., Warneke, C., Brock, C., Holloway, J. S., Atlas, E. L., and Edgerton, E.: A study of secondary organic aerosol formation in the anthropogenicinfluenced southeastern United States, J. Geophys. Res., 112, D13302, doi:10.1029/2007JD008408, 2007.

Wexler, A. S. and Clegg, S. L.: Atmospheric aerosol models for systems including the ions $\mathrm{H}^{+}, \mathrm{NH}_{4}^{+}, \mathrm{Na}^{+}, \mathrm{SO}_{4}^{2-}$, $\mathrm{NO}_{3}^{-}, \mathrm{Cl}^{-}, \mathrm{Br}^{-}$and $\mathrm{H}_{2} \mathrm{O}$, J. Geophys. Res., 107(D14), 4207, doi:10.1029/2001JD000451, 2002.

Wesely, M. L.: Use of variance techniques to measure dry airsurface exchange rates, Bound.-Lay. Meteorol., 44, 13-31, 1988.

Widory, D., Roy, S., Le Moullec, Y., Goupil, G., Cocherie, A., and Guerrot, C.: The origin of atmospheric particles in Paris: a view through carbon and lead isotopes, Atmos. Environ., 38, 953-961, 2004.

Zhang, Q., Worsnop, D. R., Canagaratna, M. R., and Jimenez, J. L.: Hydrocarbon-like and oxygenated organic aerosols in Pittsburgh: insights into sources and processes of organic aerosols, Atmos. Chem. Phys., 5, 3289-3311, doi:10.5194/acp-5-32892005, 2005. 